Prepared in cooperation with Des Moines Water Works

\title{
A Steady-State Groundwater Flow Model for the Des Moines River Alluvial Aquifer near Prospect Park, Des Moines, lowa
}

Open-File Report 2021-1110 



\section{A Steady-State Groundwater Flow Model for the Des Moines River Alluvial Aquifer near Prospect Park, Des Moines, lowa}

By Kendall M. FitzGerald, Wonsook S. Ha, Adel E. Haj, Lance R. Gruhn, Emilia L. Bristow, and Jared R. Weber

Prepared in cooperation with Des Moines Water Works

Open-File Report 2021-1110 


\section{U.S. Geological Survey, Reston, Virginia: 2022}

For more information on the USGS - the Federal source for science about the Earth, its natural and living resources, natural hazards, and the environment—visit https://www.usgs.gov or call 1-888-ASK-USGS.

For an overview of USGS information products, including maps, imagery, and publications, visit https://store.usgs.gov/.

Any use of trade, firm, or product names is for descriptive purposes only and does not imply endorsement by the U.S. Government.

Although this information product, for the most part, is in the public domain, it also may contain copyrighted materials as noted in the text. Permission to reproduce copyrighted items must be secured from the copyright owner.

Suggested citation:

FitzGerald, K.M., Ha, W.S., Haj, A.E., Gruhn, L.R., Bristow, E.L., and Weber, J.R., 2022, A steady-state groundwater flow model for the Des Moines River alluvial aquifer near Prospect Park, Des Moines, lowa: U.S. Geological Survey Open-File Report 2021-1110, 20 p., https://doi.org/10.3133/ofr20211110.

Associated data for this publication:

Ha, W.S., 2022, MODFLOW-NWT model used to simulate groundwater levels in the Des Moines River alluvial aquifer near Des Moines, lowa: U.S. Geological Survey data release, https://doi.org/10.5066/P9F3CKLC.

U.S. Geological Survey, 2021, USGS water data for the Nation: U.S. Geological Survey National Water Information System database, https://doi.org/10.5066/F7P55KJN.

ISSN 2331-1258 (online) 


\section{Acknowledgments}

The authors would like to thank Des Moines Water Works for their support of past and ongoing studies. 



\section{Contents}

Acknowledgments ……...................................................................................................................

Abstract

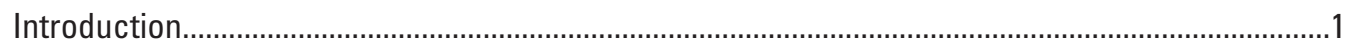

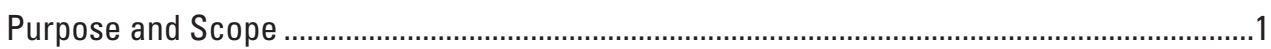

Previous Groundwater Flow Models and Investigations ..............................................................

Description of Model Area ..................................................................................................

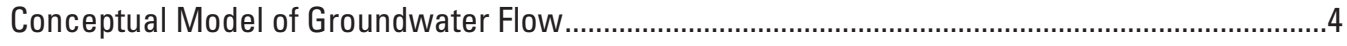

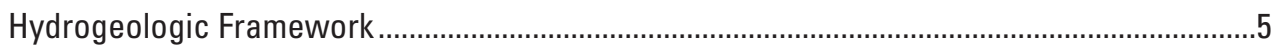

Water Budget Components ......................................................................................................

Inferred Water-Table Elevation Map .....................................................................................

Numerical Model of Groundwater Flow ...................................................................................

Numerical Model Design....................................................................................................

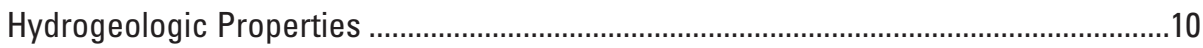

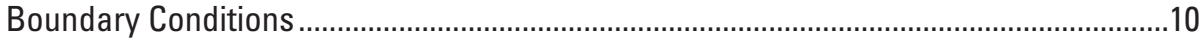

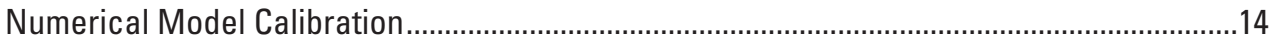

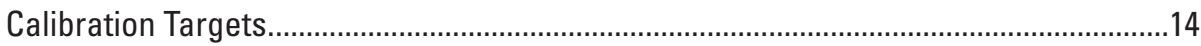

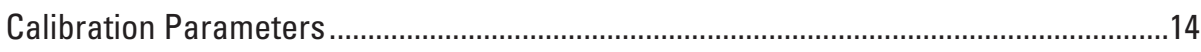

Numerical Model Calibration Results ........................................................................14

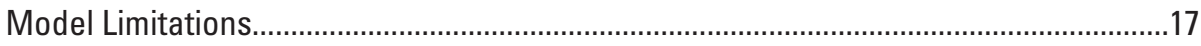

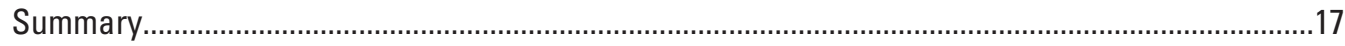

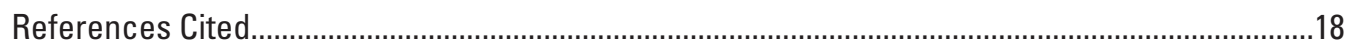

\section{Figures}

1. Map showing model area, U.S. Geological Survey streamgage, and U.S.

Geological Survey observation well .............................................................................

2. Representation of the conceptual model for the model area in Des Moines, lowa .........4

3. Map showing the elevation of the bedrock surface and the thickness and surficial extent of the alluvium and till units within the model area, with the Des Moines River valley and upland landforms indic ated .....................................................

4. Map showing inferred water-table elevations within the model area .............................8

5. Map showing hydrogeologic unit, layer thickness, river and drain boundary conditions, and calibration targets assigned to cells in layer 1 ......................................11

6. Map showing hydrogeologic unit and layer thickness values assigned to cells

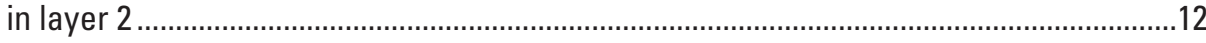

7. Cross section showing the model area along the transect shown in figures 5 and 6 ....13

8. Map showing simulated water-table elevations in layer 1 within the model area...........15

9. Graph showing simulated versus observed water-table elevations for the steady-state calibration period with a 1:1 line shown. 


\section{Tables}

1. Initial and calibrated hydraulic conductivities for Des Moines River alluvial aquifer hydrogeologic units.....

2. Volumetric water budget for the simulated stress period

\section{Conversion Factors}

U.S. customary units to International System of Units

\begin{tabular}{lcl}
\hline \multicolumn{1}{c}{ Multiply } & By & \multicolumn{1}{c}{ To obtain } \\
\hline & Length & \\
\hline inch (in.) & 2.54 & centimeter $(\mathrm{cm})$ \\
inch (in.) & 25.4 & millimeter $(\mathrm{mm})$ \\
\hline & Flow rate & \\
\hline cubic foot per second $(\mathrm{ft} 3 / \mathrm{s})$ & 0.02832 & cubic meter per $\mathrm{second}\left(\mathrm{m}^{3} / \mathrm{s}\right)$ \\
million gallons per year $(\mathrm{Mgal} / \mathrm{yr})$ & $3,785.4$ & cubic meter per year $\left(\mathrm{m}^{3} / \mathrm{yr}\right)$ \\
inch per year (in $/ \mathrm{yr})$ & 25.4 & millimeter per year $(\mathrm{mm} / \mathrm{yr})$ \\
\hline
\end{tabular}

International System of Units to U.S. customary units

\begin{tabular}{lcl}
\hline \multicolumn{1}{c}{ Multiply } & By & \multicolumn{1}{c}{ To obtain } \\
\hline centimeter $(\mathrm{cm})$ & Length & inch (in.) \\
meter $(\mathrm{m})$ & 0.3937 & foot $(\mathrm{ft})$ \\
kilometer $(\mathrm{km})$ & 3.281 & mile (mi) \\
\hline & 0.6214 & acre \\
\hline square meter $\left(\mathrm{m}^{2}\right)$ & Area & square foot $\left(\mathrm{ft}^{2}\right)$ \\
square meter $\left(\mathrm{m}^{2}\right)$ & 0.0002471 & acre \\
square kilometer $\left(\mathrm{km}^{2}\right)$ & 10.76 & square mile $\left(\mathrm{mi}^{2}\right)$ \\
square kilometer $\left(\mathrm{km}^{2}\right)$ & 247.1 & \\
\hline & 0.3861 & foot per day $(\mathrm{ft} / \mathrm{d})$ \\
\hline meter per day $(\mathrm{m} / \mathrm{d})$ & Flow rate & square foot $\mathrm{per} \mathrm{day}\left(\mathrm{ft}^{2} / \mathrm{d}\right)$ \\
\hline
\end{tabular}

Temperature in degrees Fahrenheit $\left({ }^{\circ} \mathrm{F}\right)$ may be converted to degrees Celsius $\left({ }^{\circ} \mathrm{C}\right)$ as follows:

$$
{ }^{\circ} \mathrm{F}=\left(1.8 \mathrm{x}^{\circ} \mathrm{C}\right)+32
$$




\section{Datum}

Vertical coordinate information is referenced to North American Vertical Datum of 1988 (NAVD 88).

Horizontal coordinate information is referenced to the North American Datum of 1983 (NAD 83).

Elevation, as used in this report, refers to distance above the vertical datum.

\section{Abbreviations}

$\begin{array}{ll}\text { DEM } & \text { digital elevation model } \\ \text { DMWW } & \text { Des Moines Water Works } \\ \text { DRN } & \text { Drain [Package] } \\ \text { ET } & \text { evapotranspiration } \\ \text { EVT } & \text { Evapotranspiration [Package] } \\ K_{h} & \text { horizontal hydraulic conductivity } \\ K_{z} & \text { vertical hydraulic conductivity } \\ \text { PEST } & \text { Parameter ESTimation [software] } \\ \text { RCH } & \text { Recharge [Package] } \\ \text { RIV } & \text { River [Package] } \\ \text { USGS } & \text { U.S. Geological Survey }\end{array}$





\title{
A Steady-State Groundwater Flow Model for the Des Moines River Alluvial Aquifer near Prospect Park, Des Moines, lowa
}

\author{
By Kendall M. FitzGerald, Wonsook S. Ha, Adel E. Haj, Lance R. Gruhn, Emilia L. Bristow, and Jared R. Weber
}

\section{Abstract}

The Des Moines River alluvial aquifer is an important source of water for Des Moines Water Works, the municipal water utility that provides residential and commercial water resources to the residents of Des Moines, Iowa, and surrounding municipalities. As an initial step in developing a better understanding of the groundwater resources of the Des Moines River alluvial aquifer, the U.S. Geological Survey constructed a steady-state numerical groundwater flow model in cooperation with Des Moines Water Works to simulate water-table elevations in the Des Moines River alluvial aquifer near Prospect Park in Des Moines under winter low-flow conditions.

A simple conceptual model consisting of a hydrogeologic framework, water budget, and inferred water-table elevation map was developed for the model area. The inferred water-table elevation map was constructed based on general knowledge of hydrogeology within the model area and was used to set calibration targets for numerical model calibration. A steady-state numerical model was constructed based on the conceptual model using MODFLOW-NWT to simulate an area of about 15 square kilometers near Prospect Park in Des Moines. Parameter ESTimation software was used for model calibration to assess and optimize performance of the horizontal hydraulic conductivity and recharge parameters. The numerical groundwater flow model and supporting data are available in the USGS data release associated with this report, which contains the model archive.

Performance of the calibrated steady-state model was assessed by comparing observed and simulated water-table elevations, as well as estimated and simulated contributions to streamflow within the model area. The difference between observed water-table elevations and simulated water-table elevations was -0.1 meter at the majority of calibration targets, with the negative value indicating an overestimation of the simulated water-table elevation value compared to the observed water-table elevation value, and the root mean square error was 0.13 meter, which represents about 20 percent of the difference in observed water-table elevations. The simulated value of contributions to streamflow within the model area was considered similar to the estimated value, increasing confidence in the ability of the model to accurately represent the groundwater flow system in the Des Moines River alluvial aquifer in the model area during winter low-flow conditions.

\section{Introduction}

Des Moines Water Works (DMWW) is a regional municipal water utility that provides residential and commercial water resources to the residents of Des Moines, Iowa, and surrounding municipalities (fig. 1). Des Moines is a city in Polk County, Iowa, and has a current population of about 214,000 (U.S. Census Bureau, 2019). DMWW has several production facilities that draw upon surface-water and groundwater resources, including the Des Moines River alluvial aquifer. Population growth has caused an increase in the demand for water supplies, leading DMWW to explore an expansion of their groundwater production capabilities.

DMWW is cooperating with the U.S. Geological Survey (USGS) on a series of scientific investigations to evaluate the availability and resilience of groundwater resources within the Des Moines River alluvial aquifer. The tools and data resulting from these investigations have the potential to inform production and adaptive management decisions that could allow DMWW to meet their goals of delivering high-quality water in reliable quantities while preserving a clean, sustainable water supply for the communities they serve. This report details the first of these investigations, a steady-state numerical groundwater flow model of the Des Moines River alluvial aquifer near Prospect Park in Des Moines (fig. 1). This steady-state model is an initial step in developing a better understanding of the groundwater resources of the Des Moines River alluvial aquifer near Des Moines.

\section{Purpose and Scope}

The purpose of this report is to describe a steady-state numerical groundwater flow model that was constructed for the Des Moines River alluvial aquifer near Prospect Park in Des Moines (fig. 1). The model was constructed to simulate 


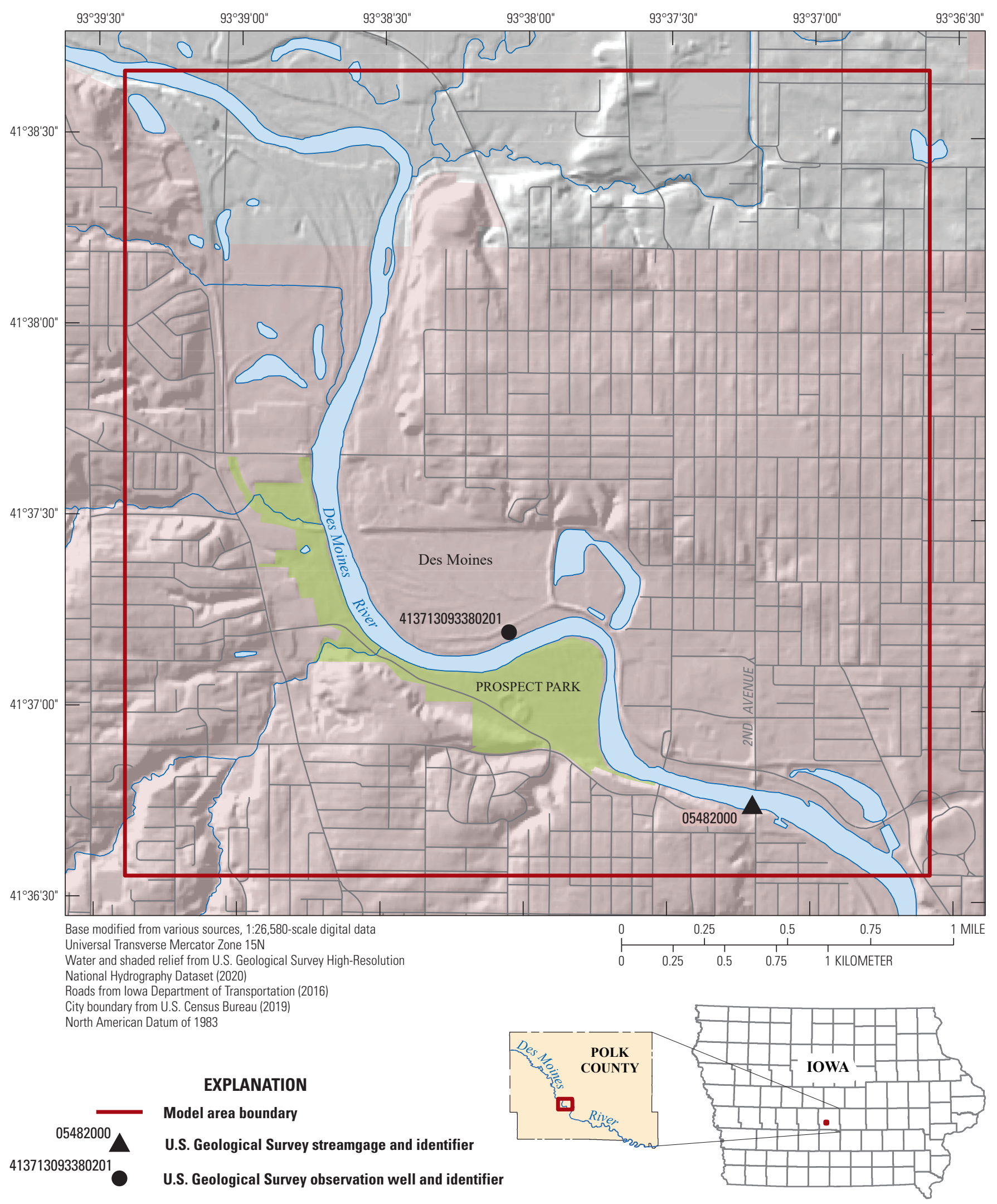

Figure 1. Model area, U.S. Geological Survey streamgage, and U.S. Geological Survey observation well. 
water-table elevations in the Des Moines River alluvial aquifer during winter low-flow conditions. These conditions were approximated by calibrating the model to inferred water-table elevations that were based on a low water-surface elevation value recorded at the streamgage within the model area from January 2015 to December 2020. This report describes the hydrogeologic framework, water budget, and inferred watertable elevation map developed for the conceptual model, and the construction of the numerical groundwater flow model including the selection of boundary conditions and model input parameters, model calibration, and model output. The numerical groundwater flow model and supporting data are available in the USGS data release associated with this report, which contains the model archive (Ha, 2022).

\section{Previous Groundwater Flow Models and Investigations}

Two groundwater flow models were previously constructed to investigate groundwater flow in central Iowa (Gannon, 2011, 2013). One groundwater flow model was constructed for the west fork of the Des Moines River alluvial aquifer, about 200 kilometers $(\mathrm{km})$ upstream from Prospect Park in Des Moines, to estimate groundwater flow and drawdown from groundwater pumping to gain a better understanding of the potential effects of a new well field on nearby irrigation wells (Gannon, 2011). Three simulation scenarios were completed: normal precipitation (30 to 32 inches per year [in/yr] of rainfall), moderate drought (20 to $22 \mathrm{in} / \mathrm{yr}$ of rainfall), and severe drought conditions (15 to $16 \mathrm{in} / \mathrm{yr}$ of rainfall). Gannon (2011) determined that induced recharge from the Des Moines River and its tributaries accounted for about 58 percent of water to the pumping wells during severe drought conditions, an increase from about 11 percent during normal rainfall conditions; the induced recharge from the river prevented high drawdowns at irrigation wells during severe drought conditions.

The second groundwater flow model simulated flow in the lower Raccoon River alluvial aquifer (not shown) near central Iowa, adjacent to the cities of Adel, De Soto, Van Meter, Waukee (cities not shown), and Des Moines (Gannon, 2013). Raccoon River is a tributary of the Des Moines River that joins the river about $4 \mathrm{~km}$ downstream from Prospect Park in Des Moines. The model was constructed to estimate the capacity of the aquifer to meet water demand during drought conditions, evaluate the interactions between surface water and groundwater, and calculate maximum sustainable pumping rates. From the simulation results, about 52 percent of water produced by the pumping wells came from the Raccoon River, 29 percent came from induced recharge from sand and gravel quarries, and 19 percent came from recharge from precipitation and groundwater flow into the model area. Particle tracking was used during the simulation and indicated that the length of time required to move a known contaminant plume to nearby wells in West Des Moines was between about 1.6 and 2.2 years.

Another study was completed to quantify the recharge rate in southern Minnesota and northern Iowa (Witt, 2017). The study by Witt (2017) was intended to assess the sustainability of drinking water resources and to determine the contamination potential of the buried-valley aquifers by estimating recharge rates in the model area. Estimated recharge values of 47 to 1,112 million gallons per year were calculated using hydraulic gradients and mean hydraulic conductivity, and groundwater age was estimated to be between about 2 and 1,026 years using isotopic age-dating methods.

\section{Description of Model Area}

The model area is within the Des Moines River drainage basin about $10 \mathrm{~km}$ downstream from the Saylorville Reservoir (not shown) and is an area of about 15 square kilometers (fig. 1). The Des Moines River flows from its headwaters in southern Minnesota to its confluence with the Mississippi River in Lee County in southeastern Iowa. The model area encompasses Prospect Park, which contains a pumping station operated by DMWW (not shown), and a part of the city of Des Moines (fig. 1). The model area also includes USGS streamgage Des Moines River at 2nd Avenue at Des Moines, Iowa (05482000), and USGS observation well 413713093380201 (fig. 1).

Iowa has a subhumid continental climate characterized by extreme seasonal variations. Based on data collected from 1991 to 2020, the mean annual temperature in Des Moines is 50.9 degrees Fahrenheit $\left({ }^{\circ} \mathrm{F}\right)$, with mean temperatures ranging from a high of $76.3^{\circ} \mathrm{F}$ in July to a low of $22.6^{\circ} \mathrm{F}$ in January (National Oceanic and Atmospheric Administration, 2021a). The mean annual precipitation in Des Moines based on data from 1991 to 2020 is about $36 \mathrm{in} / \mathrm{yr}$, with more than two-thirds of this precipitation falling between April and September, peaking in June (National Oceanic and Atmospheric Administration, 2021a). Monthly precipitation totals recorded at the Des Moines International Airport weather station for December 2018, 2019, and 2020 ranged from 1.09 to 2.90 inches (in.), averaging 1.98 in. (National Oceanic and Atmospheric Administration, 2021b).

The model area is on the southern advances of the Des Moines Lobe of the Laurentide Ice Sheet, which reached its terminal position at Des Moines about 13,800 radiocarbon years before present (Clark and others, 1993). This was followed by a readvance to the Algona Moraine about 12,300 radiocarbon years before present, during which the upper Des Moines River was formed (Bettis and Hoyer, 1986; Bettis and others, 1988). The land surface is flat to irregular, defined by the knob and kettle topography formed by glacial deposition and retreat. The predominant bedrock across the model area is the Cherokee Group of Middle Pennsylvanian 
age, which consists of light to dark shale, fossiliferous limestone, and very fine- to medium-grained sandstone (Pope and others, 2002). This unit is overlain by unconsolidated units of Quaternary age consisting of glacial till, alluvium, and outwash (hereafter collectively referred to as "till") deposited throughout the Pre-Illinoian, Wisconsin, and Hudson glacial episodes (Bettis and others, 1988; Quade and others, 2003).

The Des Moines River alluvial aquifer consists of unconsolidated alluvial and eolian sand and gravel deposits of Quaternary age that are highly irregular in grain size and overall thickness (Thompson, 1984). The mean thickness of these nonuniform deposits in the model area is about 6 meters (m) and ranges from about 2 to $12 \mathrm{~m}$ (Thompson, 1984). Underlying the Des Moines River alluvial aquifer within the model area is the Cherokee Group, a bedrock unit hereafter referred to as "bedrock."

Regional groundwater in the model area flows generally toward the Des Moines River, with the local water table approximating the topography of the land surface (Gannon, 2011). The Des Moines River is a gaining stream during most of the year, except during high river stage when bank storage may cause a temporary reversal of flow direction (Gannon, 2011). Recharge to the Des Moines River alluvial aquifer in the model area is from infiltration of precipitation, infiltration of runoff from adjacent upland areas, and seepage from the underlying bedrock aquifer.

\section{Conceptual Model of Groundwater Flow}

A simple conceptual model consisting of a hydrogeologic framework, water budget, and inferred water-table elevation map was developed for the model area to aid in construction of the numerical groundwater flow model (fig. 2). In the model area, surficial sediments and bedrock were conceptualized as four hydrogeologic units: fine-grained alluvium, coarse-grained alluvium, till, and bedrock. The fine- and coarse-grained alluvium units have a fairly high permeability and constitute the alluvial aquifer. An aquifer is a geologic formation (or group of formations) that contains sufficient saturated permeable material to yield substantial quantities of water to wells. The expected yield of wells in the Des Moines River alluvial aquifer in the model area has not been quantified but depends on the thickness and interconnectedness of the alluvium units and the distribution of grain size within the units (Gannon, 2011). The till and bedrock units have a lower permeability and are considered confining units within the model area because they are capable of slowly transmitting water to the adjacent alluvium aquifer units but do not readily yield water to wells.

The model area contains several types of hydrologic boundaries, including the elevation of the Des Moines River and its perennial tributaries. Topographic highs are at the south and west boundary (fig. 1), and water-table elevations were considered constant in these areas during the simulated period. Water-table elevations also were considered constant at a high-elevation area northeast of the Des Moines River that indicates the presence of a groundwater divide. Groundwater flow away from the divide to the north and east boundaries of the model is restricted by the presence of low-conductivity till and bedrock and is intercepted by tributary streams (fig. 1). Therefore, groundwater flow at the north and east boundaries was considered constant and was not considered to affect flow within the alluvial aquifer during the simulated period.

Groundwater inflows (positive hydrologic fluxes) to the system include seepage from the Des Moines River and infiltration of precipitation that is within the model area. Groundwater outflows (negative hydrologic fluxes) from the system include evapotranspiration (ET) and contributions to streamflow in the Des Moines River and its tributaries. No

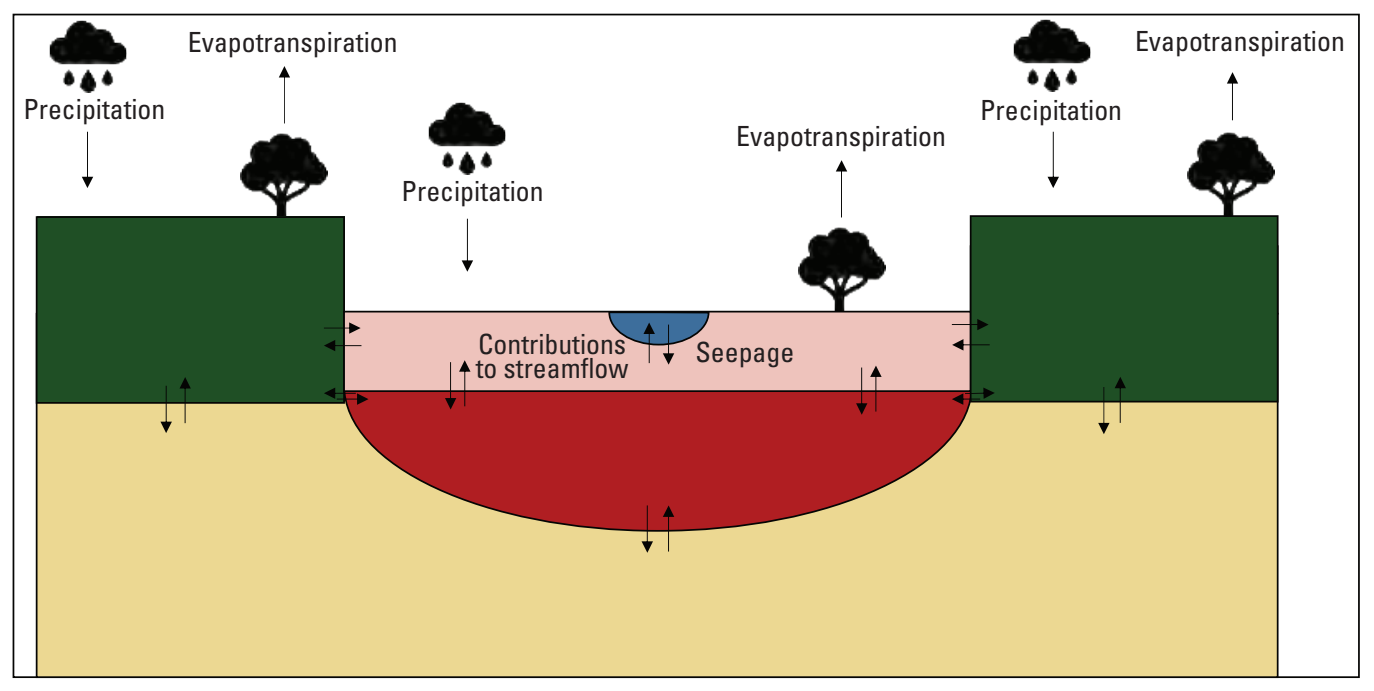

EXPLANATION

Stream channel

Fine-grained alluvium

Coarse-grained alluvium

Till

Bedrock

Hydrologic flux

Figure 2. Representation of the conceptual model for the model area in Des Moines, lowa. 
groundwater pumping wells or springs are within the model area. Oxbow lakes, remnants of former meanders of the Des Moines River, are present in the model area but were not conceptualized as surface-water features because they are direct expressions of groundwater at the land surface and have no other sources of inflow or outflow.

An inferred water-table elevation map was constructed based on general knowledge of hydrogeology within the model area. Water-table elevations from this map were later used as calibration targets during numerical model calibration. A description of this inferred water-table elevation map and how it was constructed is included in the "Inferred WaterTable Elevation Map” section.

\section{Hydrogeologic Framework}

A hydrogeologic framework (framework) is a threedimensional model of the hydrogeologic units, the hydraulic relations among these units, and the inflows to and outflows from the groundwater flow system within the model area. The framework was constructed using the conceptual model of groundwater flow described previously, detailed bedrock elevation and surficial geology maps (Pope and others, 2002; Quade and others, 2003; Witzke and others, 2010), and hydraulic relations and characteristics published in previous reports (Thompson, 1984; Lucey, 1991; Gannon, 2011, 2013). The framework was used to construct the numerical model of groundwater flow and was discretized to the spatial resolution of the numerical model grid, a 30-m square cell size, for the model area. The framework also was used to determine the number of model layers, layer thicknesses, and initial hydrologic characteristics for the numerical model, discussed in the "Numerical Model Design" section of this report.

The four hydrogeologic units for the framework (units) include fine-grained alluvium, coarse-grained alluvium, till, and bedrock. These units were identified, delineated, and interpolated in three dimensions for the framework using previous lithostratigraphic models (Gannon, 2011, 2013), existing maps of bedrock elevation and surficial geology (Pope and others, 2002; Quade and others, 2003; Witzke and others, 2010), and geophysical data collected within the Des Moines River alluvial aquifer by the USGS (Gruhn and others, 2021). A description of each unit and how the thickness, extent, and hydraulic conductivity of the unit were determined is included in this section.

Fine- and coarse-grained alluvium in the model area is within the Des Moines River valley and is composed primarily of sands and gravels that were deposited by the Des Moines River and its tributaries (fig. 3). The thicknesses of the alluvium units in the model area were determined by taking the difference between land surface elevation in the Des Moines River valley, determined from a digital elevation model (DEM; State of Iowa, 2010), and the elevation of the top of the bedrock unit, determined using the process described in this section. The combined thickness of the fine- and coarsegrained alluvium units in the Des Moines River valley within the model area ranges from about 3 to $20 \mathrm{~m}$ (fig. 3).

A core collected in September 2018 during the drilling of USGS observation well 413713093380201 (fig. 1) was subsampled to improve understanding of the hydrologic characteristics of the units within the model area. The core is about 3.8 centimeters in diameter and was collected using a Geoprobe to a depth of about $17 \mathrm{~m}$, which is deeper than the completed well depth of about $4 \mathrm{~m}$. Grain-size analysis was completed on subsamples from the core at the USGS sediment laboratory in Iowa City. Horizontal hydraulic conductivity $\left(K_{h}\right)$ was then determined for the fine- and coarse-grained alluvium units in the model area using HydrogeoSieveXL, a freely available program that calculates hydraulic conductivity from grain-size distribution curves using multiple methods (Devlin, 2015). The mean $K_{h}$ value of the fine-grained alluvium unit was estimated to be 26.28 meters per day $(\mathrm{m} / \mathrm{d})$. This mean value is based on 1 subsample collected from a depth interval of about 3 to $4.5 \mathrm{~m}$ below land surface and was calculated using 7 methods for determining hydraulic conductivity from the distribution of grain sizes, with results ranging from 13.67 to $35.06 \mathrm{~m} / \mathrm{d}$. The mean $K_{h}$ value for the coarse-grained alluvium unit was estimated to be $64.11 \mathrm{~m} / \mathrm{d}$. This value is based on six subsamples that represent the depth interval from about 4.5 to $13.7 \mathrm{~m}$ below the top of the core. The $K_{h}$ value for the coarse-grained alluvium unit across these 6 subsamples and the 7 methods used to determine $K_{h}$ value ranged from 15.38 to $122.93 \mathrm{~m} / \mathrm{d}$. Hydraulic conductivity was considered uniform in all horizontal orientations within the model area because no known fractures or similar features that would cause horizontal anisotropy are in the model area. Vertical hydraulic conductivity $\left(K_{z}\right)$ for each unit in the model area was determined from the $K_{h}$ values using a standard vertical-to-horizontal hydraulic conductivity anisotropy ratio of 1:10 (Todd, 1980).

The Des Moines River valley is bounded on either side by steep bluff slopes, with the higher elevation land outside of the Des Moines River valley in the model area referred to as "uplands" (fig. 3). In the Des Moines River valley, till has been eroded by the river, and alluvial sediments overlie the bedrock surface; in the uplands, till overlies the bedrock unit and is exposed at the land surface (Quade and others, 2003). The thickness of the till unit in the uplands was determined by taking the difference between land surface elevation, determined from a DEM (State of Iowa, 2010), and the elevation of the top of the bedrock unit, determined using the process described in this section. The thickness of the till unit in the uplands within the model area ranges from about 2 to $43 \mathrm{~m}$ (fig. 3). The $K_{h}$ value of the till unit was estimated to be $0.09144 \mathrm{~m} / \mathrm{d}$ based on previously published values (Thompson, 1984; Lucey, 1991).

The top of the bedrock unit in the model represents the top of the Cherokee Group, which is the shale, limestone, and sandstone bedrock unit that underlies the Des Moines River alluvial aquifer within the model area. The elevation of the 


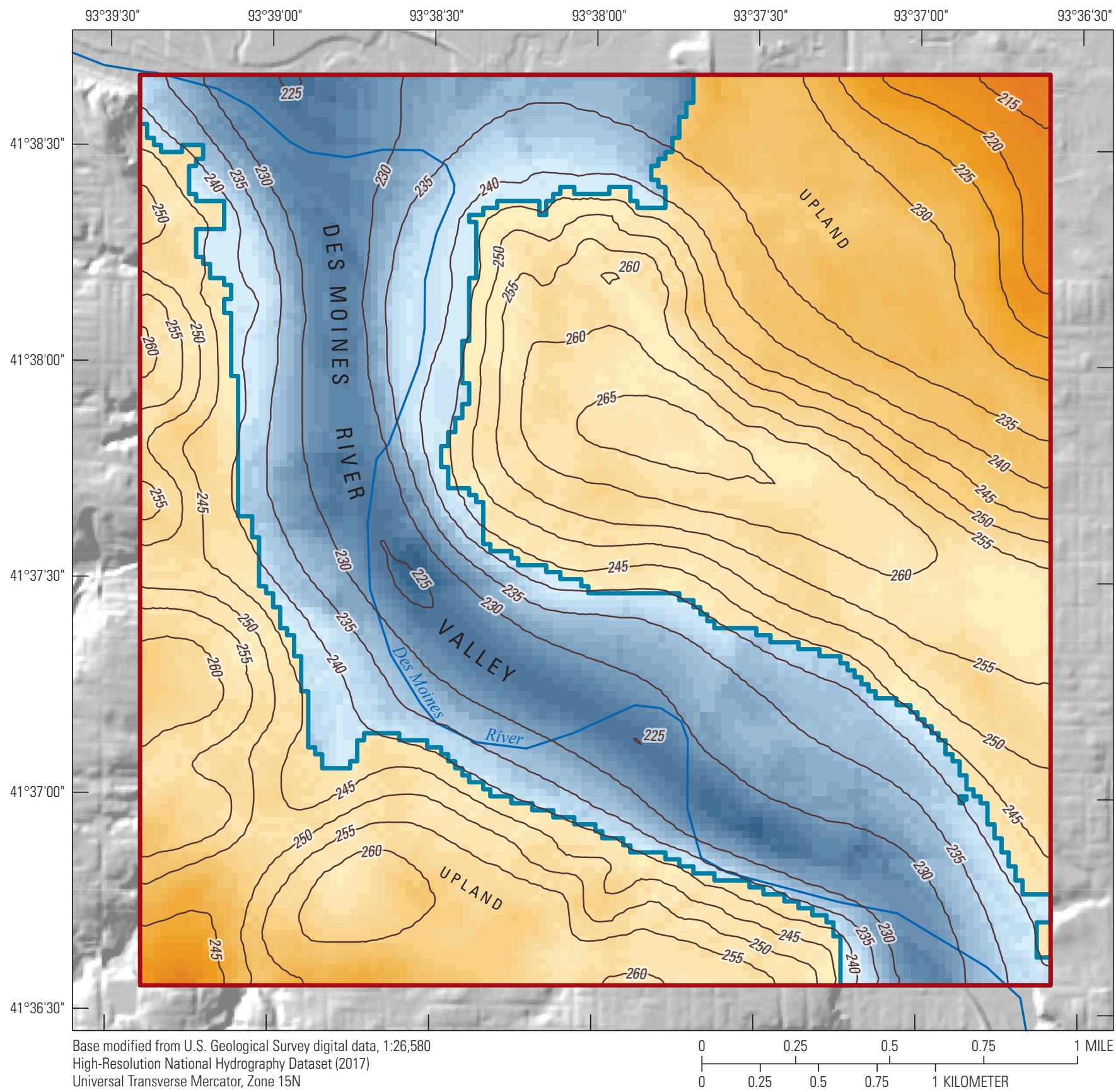

Universa Transverse Mercator, Zone 15N

North American Datum of 1983

\section{EXPLANATION}

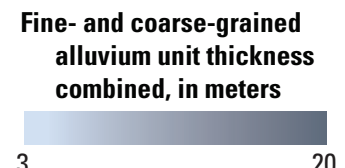

Till unit thickness, in meters
Model area boundary

Boundary between Des Moines River valley and upland landforms

Bedrock contour-Shows elevation of bedrock surface. Contour interva 5 meters. Datum is North American Vertical Datum of 1988

Des Moines River centerline

Figure 3. The elevation of the bedrock surface and the thickness and surficial extent of the alluvium and till units within the model area, with the Des Moines River valley and upland landforms indicated. 
top of this unit was determined using Iowa Geological Survey bedrock elevation maps (rasters) and lithologic logs from the GeoSam database (Witzke and others, 2010; Iowa Geological Survey, 2018), as well as geophysical data collected by the USGS (Gruhn and others, 2021). Contour lines were created from the Iowa Geological Survey bedrock surface elevation map (Witzke and others, 2010) and modified to accommodate additional geophysical data collected within the Des Moines River alluvial aquifer by the USGS (Gruhn and others, 2021). Geophysical surveys completed by the USGS in the Des Moines River alluvial aquifer include continuous resistivity profiling, continuous seismic profiling, electrical resistivity tomography, and horizontal-to-vertical spectral ratio passive seismic measurements, the data from which are available in a USGS data release (Gruhn and others, 2021). When a contour line was moved to incorporate information from these geophysical surveys, its neighboring contour lines were moved as well to maintain geomorphologic consistency. Although the use of these contours results in a highly smoothed and interpolated surface, this is justified because of the lack of high-resolution bedrock surface data for the model area. The bottom of the bedrock unit was set at an elevation of $150 \mathrm{~m}$ above the North American Vertical Datum of 1988 (NAVD 88) in the framework, resulting in bedrock unit thicknesses within the model area ranging from about 75 to $111 \mathrm{~m}$. The arbitrary elevation assigned to the bottom of the bedrock unit was made with the assumption that groundwater flow processes at this depth do not have a substantial effect on groundwater flow in the Des Moines River alluvial aquifer. The $K_{h}$ value of the bedrock unit was estimated to be $0.09144 \mathrm{~m} / \mathrm{d}$ based on previously published values (Thompson, 1984; Lucey, 1991).

\section{Water Budget Components}

A water budget consists of inflows to and outflows from the groundwater system. Two of the water budget components, recharge and ET, were estimated to provide the data needed to develop, calibrate, and simulate a steady-state groundwater flow model of the Des Moines River alluvial aquifer in the area of Prospect Park. An initial recharge rate of $0.001 \mathrm{~m} / \mathrm{d}$, which is less than mean annual precipitation in the model area, was used to represent precipitation on the land surface that infiltrates into the groundwater system; this value was later adjusted through model calibration. A winter monthly mean potential ET rate of $0.000015 \mathrm{~m} / \mathrm{d}$ was calculated by averaging daily mean values of potential ET recorded in December 2020 at an Iowa State University Soil Moisture Network station about $47 \mathrm{~km}$ north of the model area (AMFI4; Iowa State University, 2020). This value for ET was considered reasonable when compared to the mean rainfall in December 2020 within the model area, which equals $1.98 \mathrm{in}$. (or $0.0503 \mathrm{~m}$ ), meaning that ET represents less than 0.1 percent of total rainfall in December. An estimate of streamflow contribution to the Des Moines River was not used in initial model construction or Parameter ESTimation (PEST) calibration but was subsequently used as a check of model performance, as described in the "Numerical Model Calibration Results" section. No groundwater is pumped from wells within the model area, and oxbow lakes in the model area were not included as sources of inflow to or outflow from the groundwater system because they are direct expressions of groundwater and have no other inputs or outputs within the system.

\section{Inferred Water-Table Elevation Map}

A contour map of inferred water-table elevations was constructed for the model area to aid in setting calibration targets for the numerical model (fig. 4). The water-table elevations within the model area were estimated using three assumptions: (1) the water table approximates topography, (2) water-table elevations are below land surface, and (3) water-table elevations do not fall below the water-surface elevation of the Des Moines River within the model area because the Des Moines River within the model area is a gaining river during most of the year, including during winter low-flow conditions.

For the third assumption, the water-surface elevation for the Des Moines River within the model area was based on a water-surface elevation of about $239.8 \mathrm{~m}$ above the National Geodetic Vertical Datum of 1929 at the downstream USGS streamgage Des Moines River at 2nd Avenue in Des Moines, Iowa (05482000), because the water-surface elevation of the river did not typically fall to less than this value at this streamgage from January 2015 to December 2020, falling to less than $239.8 \mathrm{~m} 11$ times during those 5 years (U.S. Geological Survey, 2021c). An approximate stream gradient was calculated by dividing the difference between simultaneous water-surface elevation measurements at the upstream USGS streamgage at the Saylorville Dam (Des Moines River near Saylorville, Iowa; 05481650), about $10 \mathrm{~km}$ upstream from the model area (not shown), and the downstream USGS streamgage (Des Moines River at 2nd Avenue at Des Moines, Iowa; 05482000) by the river channel distance between them. Cells were then assigned a water-surface elevation above NAVD 88 using river stage at the downstream streamgage based on the calculated gradient and their channelwise distance upstream from the streamgage.

The water-table elevation within the model area was then interpolated from control points, which are locations in the model area where the water-table elevation is assumed to be known. In the floodplain, transects were created perpendicular to each river cell, and control points were set based on river elevation in the cell along the transect and adjusted for topography. On upland peaks, the control points were fixed at $6 \mathrm{~m}$ below land surface. This is an arbitrary value because of the lack of water-level data in the uplands of the model area and is justified because water-table elevations in the uplands have little effect on groundwater flow within the Des Moines River alluvial aquifer and were not used in model calibration. Interpolated water levels were adjusted in a few cells 


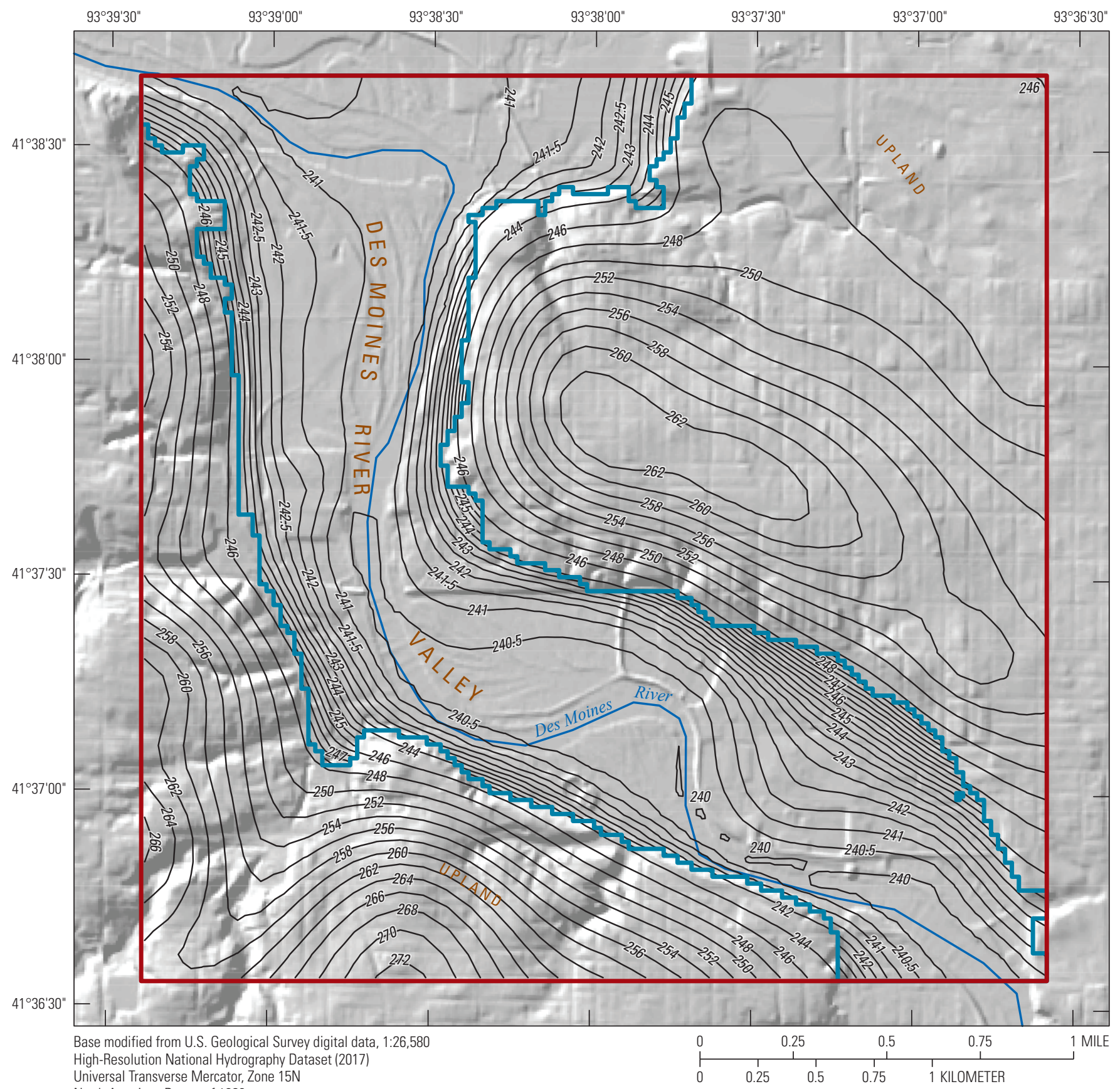

Universal Transverse Mercator, Zone 15N

North American Datum of 1983

EXPLANATION

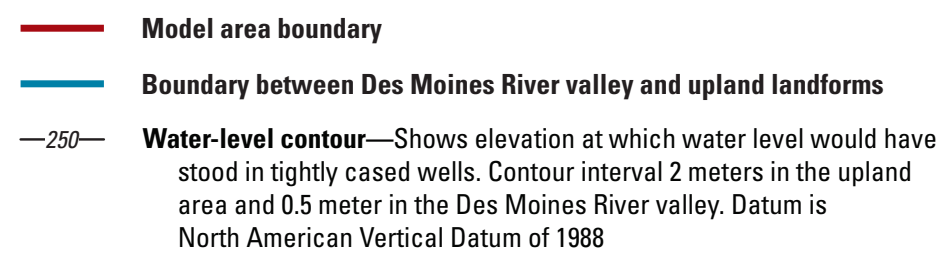

Des Moines River centerline

Figure 4. Inferred water-table elevations within the model area. 
to stay at or below land surface and to fill in unwanted sinks where the water-table surface does not accurately approximate topography. The inferred water-table elevation values used to create this contour map are available in the USGS data release associated with this report, which contains the model archive (Ha, 2022).

The inferred water-table elevation map was validated for winter low-flow conditions by comparing the inferred watertable elevation and the observed elevation at USGS observation well 413713093380201 during December 2020. During that time, the observation well recorded a mean water-table elevation of $240.4 \mathrm{~m}$ (NAVD 88), calculated by averaging daily water-table elevation values recorded at the well (U.S. Geological Survey, 2021d). The water-table elevation at this location from the inferred water-table map is $240.1 \mathrm{~m}$ and was considered a satisfactory approximation of the observed water-table elevation at the observation well. The similarity between the observed and simulated water-table elevations at this location indicates that the inferred water-table elevation map adequately represents groundwater conditions in the model during winter low-flow conditions and can be used in setting calibration targets for the numerical model near the observation well.

\section{Numerical Model of Groundwater Flow}

A three-dimensional numerical groundwater flow model of the Des Moines River alluvial aquifer, hereafter referred to as "the model," was constructed to simulate the elevation of the water table under winter low-flow conditions. The numerical model was constructed using MODFLOW-NWT (Niswonger and others, 2011), a USGS-constructed threedimensional finite difference groundwater modeling software, and calibrated using PEST software (Doherty, 2004; Doherty and Hunt, 2010). All numerical model input and output files are available in the USGS data release associated with this report, which contains the model archive (Ha, 2022).

\section{Numerical Model Design}

A steady-state numerical model was constructed using MODFLOW-NWT (version 1.1.4; Niswonger and others, 2011) to simulate the elevation of the water table during steady-state (mean) conditions representing a winter low-flow scenario. MODFLOW-NWT is a Newton-Raphson formulation for MODFLOW-2005 (Harbaugh, 2005) that improves the solution of unconfined groundwater flow problems. It solves the groundwater flow equation for a set of discrete blocks, called "cells," and balances all inflows and outflows for each cell in the model area. Various components of the water budget were simulated using MODFLOW model packages included in MODFLOW-NWT. Packages simulate a stress or boundary condition in the model and were selected based on the components of the conceptual model. Aquifer storage was not used in the formulations of the groundwater flow equation because it is considered negligible during steady state.

Packages used to define groundwater flow processes within the model include the Basic (Harbaugh and others, 2000), Discretization (Harbaugh and others, 2000), Zone (Harbaugh and others, 2000), and Upstream Weighting (Niswonger and others, 2011) Packages. The Basic Package was used to distribute initial hydraulic heads to model cells at an elevation equal to the elevation of the top of layer 1; the Discretization Package was used to define the extent and geometry of layers included in the numerical model; the Zone Package was used to specify hydrogeologic units within a layer that were later used in PEST calibration; and the Upstream Weighting Package was used to specify properties controlling flow between cells and is required when using the MODFLOW-NWT solver. The packages used to simulate stresses to groundwater flow include the Recharge (RCH; Harbaugh and others, 2000), Evapotranspiration (EVT; McDonald and Harbaugh, 1988), Drain (DRN; Harbaugh, 2005), and River (RIV; Harbaugh and others, 2000) Packages. The RCH Package was used to represent infiltration from precipitation in the model area, the EVT Package was used to represent ET from groundwater in the model area, the DRN Package was used to simulate head-dependent flux in tributary cells in the model area (Winston, 2018), and the RIV Package was used to simulate head-dependent flux in river cells.

The model area is an area of about 15 square kilometers within the Des Moines River drainage basin and encompasses Prospect Park and a part of the city of Des Moines (fig. 1). The model grid contains cells that are $30-\mathrm{m}$ square (900 square meters $\left[\mathrm{m}^{2}\right]$ ) and is composed of 130 rows (oriented west to east) and 130 columns (oriented north to south). The model is vertically discretized into 3 layers that are used to represent the 4 hydrogeologic units (fine-grained alluvium, coarsegrained alluvium, till, and bedrock) described in the framework. The top of layer 1 represents the mean land surface elevation in each model cell as determined based on a DEM of the model area (State of Iowa, 2010). The bottom of layer 3 is the bottom of the bedrock unit in the framework, which was set at an arbitrary elevation of $150 \mathrm{~m}$ above NAVD 88 . Elevations of the top and bottom of each cell for each layer and their unit values are available in the USGS data release associated with this report, which contains the model archive (Ha, 2022).

The spatial extent and thickness of units assigned to model layers were determined from unit thickness, extent, and superposition in the hydrogeologic framework. Layer 1 represents fine-grained alluvium in the Des Moines River valley cells and till in the upland cells, as described in the framework (fig. 5). Fine-grained alluvium was assigned a thickness of $2 \mathrm{~m}$, except in cells in and around the river where thickness was adjusted to allow for $3 \mathrm{~m}$ of thickness in layer 1 to accommodate the water-surface elevations in the river. Although the core collected from USGS observation well 413713093380201 contained fine-grained alluvium to a depth of about $5 \mathrm{~m}$, this 
was considered to be an overestimation of the mean thickness of fine-grained alluvium in the model area because the core was collected in the wetlands of the Des Moines River, so a lower value of $2 \mathrm{~m}$ was considered to be a more appropriate estimate for the thickness of the fine-grained alluvium unit in areas away from the river. Thickness also was adjusted in cells distal from the river where a larger thickness was required to maintain geomorphologic consistency (fig. 5). Cells designated "fine-grained alluvium" are between about 2 and $15 \mathrm{~m}$ thick, and cells designated "till" are between about 3 and $43 \mathrm{~m}$ thick.

Layer 2 represents coarse-grained alluvium in the Des Moines River valley cells and bedrock in the upland cells, with the thickness of the coarse-grained alluvium varying between about 1 and $18 \mathrm{~m}$ (fig. 6). Coarse-grained alluvium was assigned the remaining thickness between the bottom of the fine-grained alluvium and the surface of the underlying bedrock, with a minimum thickness of $1 \mathrm{~m}$. Where there was not at least $1 \mathrm{~m}$ between the bottom of the fine-grained alluvium and the top of the bedrock, the bedrock surface was moved down to accommodate at least $2 \mathrm{~m}$ of fine-grained alluvium and $1 \mathrm{~m}$ of coarse-grained alluvium. Because coarsegrained alluvium is not present outside of the alluvial cells, upland cells in layer 2 were assigned the value of the underlying unit (bedrock) and given a thickness of $1 \mathrm{~m}$. Layer 3 represents the extent of the bedrock unit to an arbitrary depth of $150 \mathrm{~m}$ above NAVD 88, and the thickness ranges from 62 to $116 \mathrm{~m}$. A cross section of the model area along the transect shown in figures 5 and 6 shows the positions and thicknesses of each layer (fig. 7).

\section{Hydrogeologic Properties}

Values for $K_{h}$ and $K_{z}$ were estimated for each hydrogeologic unit in the model (table 1). These values were initially assigned based on grain-size distributions for the fine-grained and coarse-grained alluvium units, as described in the "Hydrogeologic Framework" section, as well as the interpretation of mapped geologic data, geophysical subsurface information, lithologic logs, and previously published estimates for hydrogeologic properties (Thompson, 1984; Lucey, 1991; Pope and others, 2002; Quade and others, 2003; Witzke and others, 2010; Gannon, 2011, 2013). Fine-grained alluvium was assigned an initial $K_{h}$ value of $26.28 \mathrm{~m} / \mathrm{d}$ and a $K_{z}$ value of $1.15 \mathrm{~m} / \mathrm{d}$, coarse-grained alluvium was assigned an initial $K_{h}$ value of $64.11 \mathrm{~m} / \mathrm{d}$ and a $K_{z}$ value of $2.628 \mathrm{~m} / \mathrm{d}$, till was assigned an initial $K_{h}$ value of $0.09144 \mathrm{~m} / \mathrm{d}$ and a $K_{z}$ value of $0.009144 \mathrm{~m} / \mathrm{d}$, and bedrock was assigned an initial $K_{h}$ value of $0.09144 \mathrm{~m} / \mathrm{d}$ and a $K_{z}$ value of $0.009144 \mathrm{~m} / \mathrm{d}$. Because this is a steady-state model, aquifer storage characteristics such as specific storage and specific yield were not assigned.

\section{Boundary Conditions}

Boundary conditions represent areas of the model domain where water flows into or out of the groundwater system. Boundary conditions in the numerical model were simulated using various MODFLOW packages. Recharge that is from infiltration of precipitation in the model area was simulated using the RCH Package, direct ET from groundwater was simulated using the EVT Package, and the interaction of groundwater and surface water in the model area was simulated using the RIV and DRN Packages.

The north and east model boundaries were considered no-flow boundaries because of their proximity to a groundwater divide as described in the conceptual model. For the model boundaries in the Des Moines River valley or near the tributaries, river and drain cells provided a strong control on constant head boundary conditions. The south and west model boundaries also were considered no-flow boundaries because of their proximity to a groundwater divide. The no-flow boundary and constant head boundary conditions were selected because they provide minimal effect on the model simulation and were capable of replicating water-table elevations such as those presented in the conceptual model.

Recharge from infiltration of precipitation on the land surface was simulated using the RCH Package. The RCH Package is designed to simulate spatially distributed recharge to the groundwater system (Langevin and others, 2017). The rate of recharge is specified in units of length per time (meters per day in this case), and the rate is multiplied by the cell horizontal area to obtain the recharge flow rate for each model cell (Langevin and others, 2017). Recharge was applied uniformly to layer 1 of the model at an initial rate of $0.001 \mathrm{~m} / \mathrm{d}$, which was the rate for the conceptual model.

ET that is from direct evaporation of ground surface and from plant transpiration was simulated using the EVT Package (Langevin and others, 2017). ET simulation was based on the following assumptions: (1) when the water table is at or above a specified elevation (the "ET surface"), ET loss is at a specified fixed rate; (2) when the depth of the water table below the ET surface exceeds a depth below land surface of $1 \mathrm{~m}$, ET ceases; and (3) between these limits, ET varies in a piecewise-linear fashion with water-table elevation. An initial ET rate of $0.000015 \mathrm{~m} / \mathrm{d}$, which was the monthly mean potential ET rate calculated for December 2020 as described in the "Water Budget Components" section, was applied uniformly to layer 1 of the model.

Surface-water features in the model area contribute water to, or drain water from, the groundwater system, depending on the hydraulic head gradient between the surface-water feature and the water table. The Des Moines River and its tributaries were the only surface-water features represented in the model and were simulated using the RIV and DRN Packages (Langevin and others, 2017). The RIV Package was assigned to a model cell in layer 1 if at least one-half of the cell was covered by the Des Moines River based on aerial imagery. Attributes required to define each model cell simulated by the 


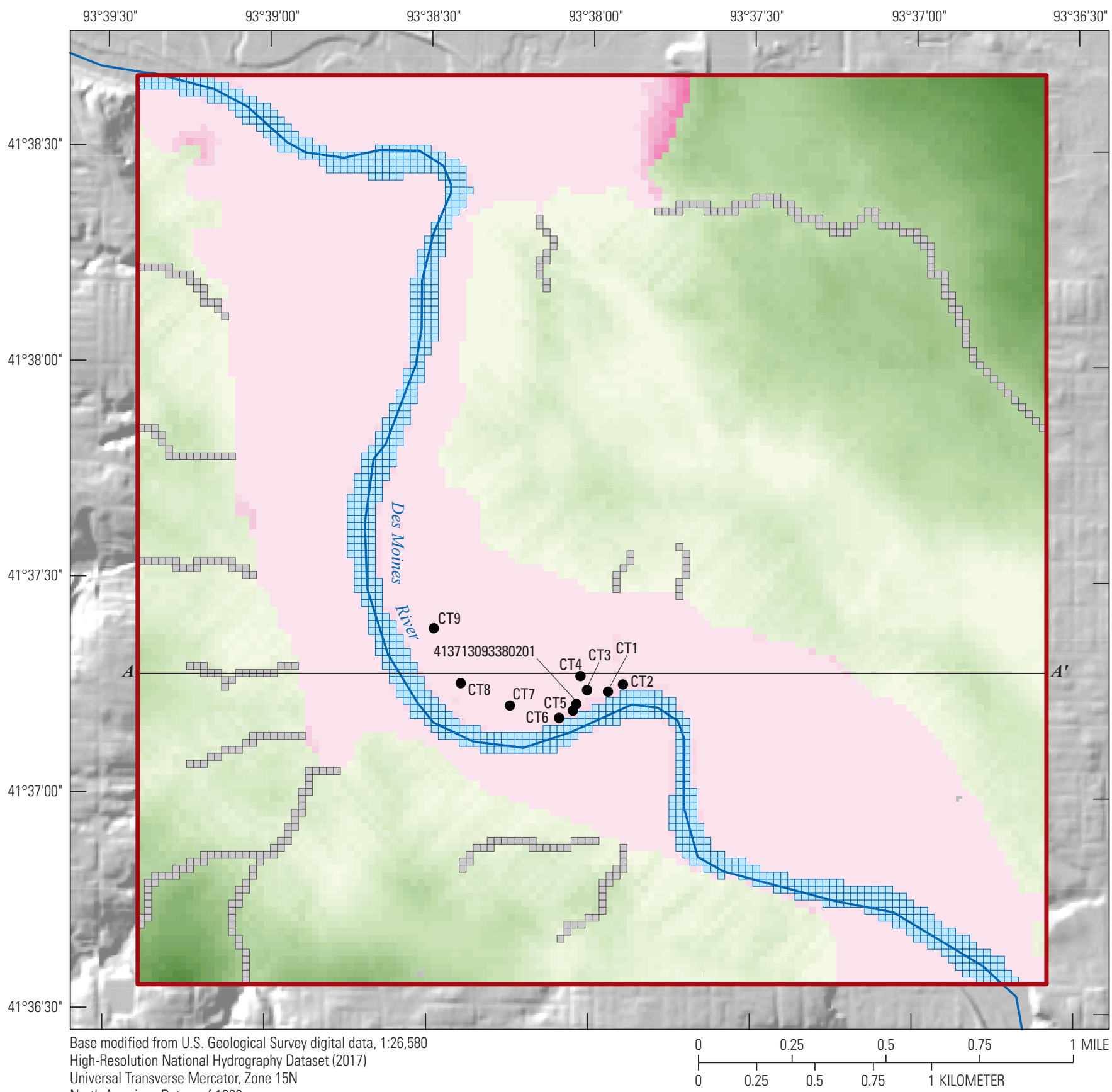

Universal Transverse Mercator, Zone $15 \mathrm{~N}$

North American Datum of 1983

EXPLANATION

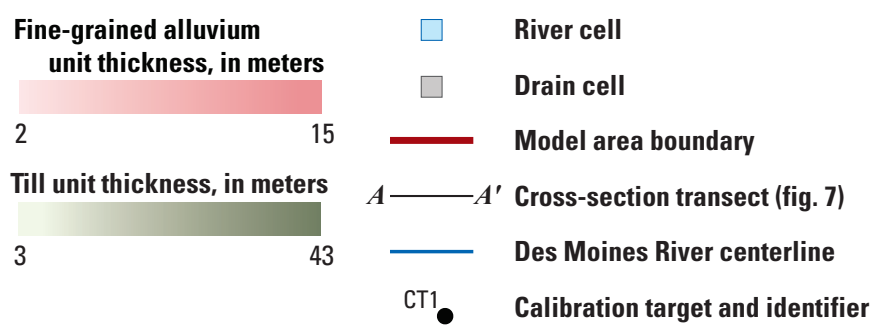

Figure 5. Hydrogeologic unit, layer thickness, river and drain boundary conditions, and calibration targets assigned to cells in layer 1. 

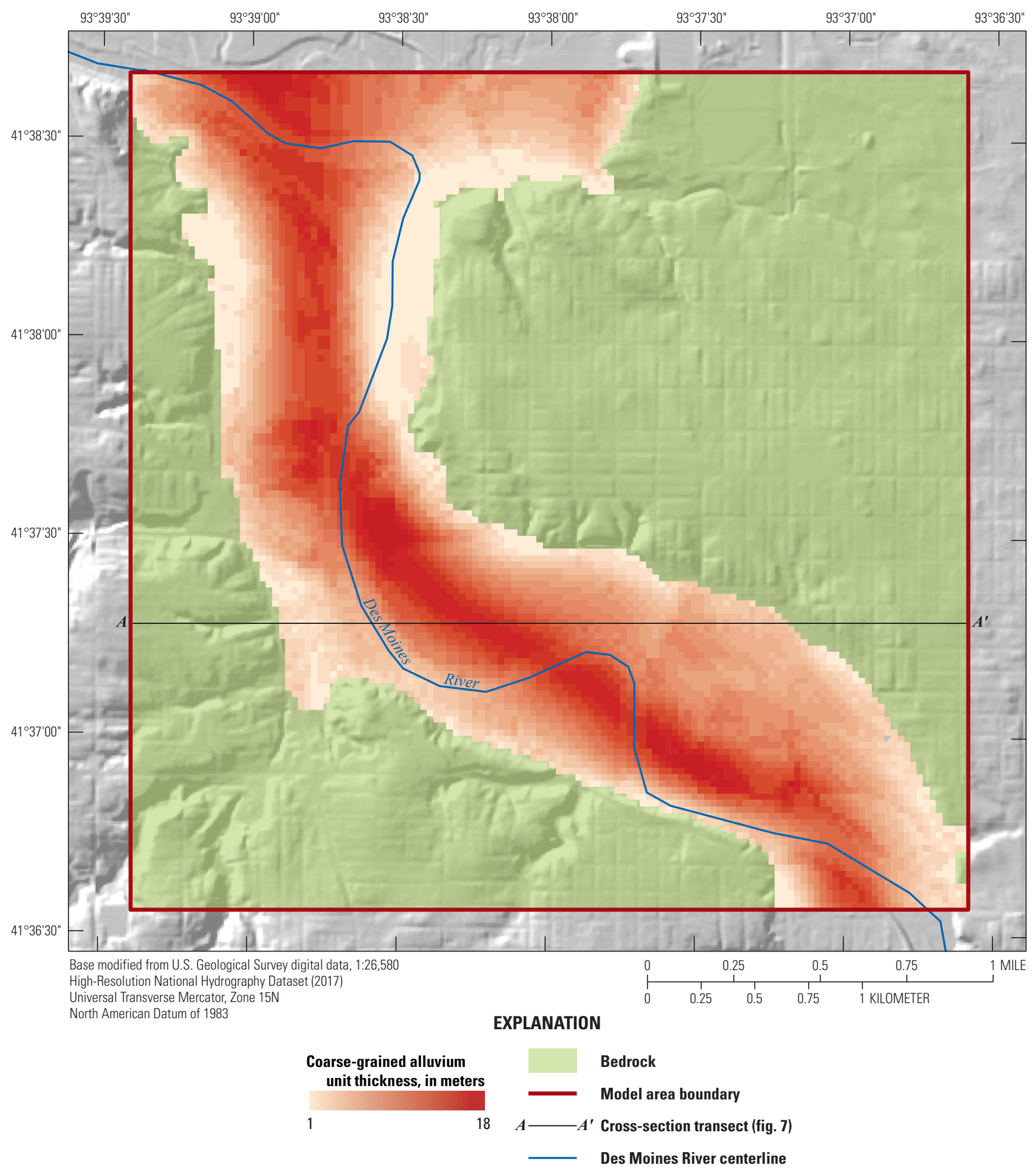

Figure 6. Hydrogeologic unit and layer thickness values assigned to cells in layer 2. 


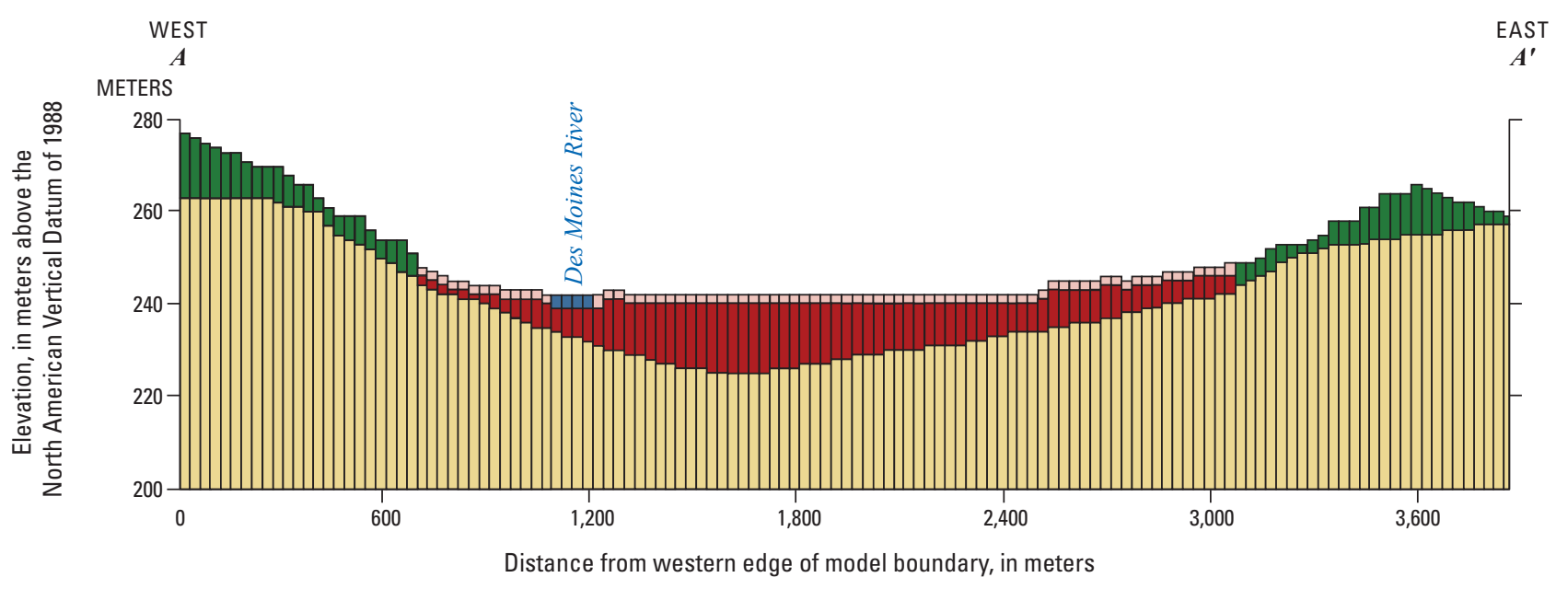

\section{EXPLANATION}

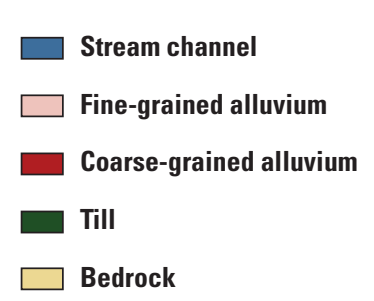

Figure 7. The model area along the transect shown in figures 5 and 6.

Table 1. Initial and calibrated hydraulic conductivities for Des Moines River alluvial aquifer hydrogeologic units.

[ $K_{h}$, horizontal hydraulic conductivity; $\mathrm{m} / \mathrm{d}$, meter per day; $K_{z}$, vertical hydraulic conductivity]

\begin{tabular}{lcccc}
\hline \multicolumn{1}{c}{ Unit } & $\begin{array}{c}\text { Initial } \boldsymbol{K}_{\boldsymbol{h}} \\
(\mathbf{m} / \mathbf{d})\end{array}$ & $\begin{array}{c}\text { Calibrated } \boldsymbol{K}_{\boldsymbol{h}} \\
(\mathbf{m} / \mathbf{d})\end{array}$ & $\begin{array}{c}\text { Initial } \boldsymbol{K}_{\mathbf{z}} \\
(\mathbf{m} / \mathbf{d})\end{array}$ & $\begin{array}{c}\text { Calibrated } \boldsymbol{K}_{\mathbf{z}} \\
(\mathbf{m} / \mathbf{d})\end{array}$ \\
\hline Fine-grained alluvium & 26.28 & 13.14 & 1.15 & 1.15 \\
Coarse-grained alluvium & 64.11 & 25.00 & 2.628 & 2.628 \\
Till & 0.09144 & 0.13716 & 0.009144 & 0.009144 \\
Bedrock & 0.09144 & 0.09144 & 0.009144 \\
\hline
\end{tabular}

RIV Package (river cell) include the water-surface elevation of the river, the elevation of the riverbed, and the conductance of the riverbed material, in square meters per day. The water-surface elevation for each river cell was estimated using the method described in the "Inferred Water-Table Elevation Map" section. The elevation of the riverbed for each model cell was estimated by subtracting $0.9 \mathrm{~m}$ from the water-surface elevation of the river in that cell. This was an estimated value of the thickness of the surface water at each river cell and was kept constant along the length of the river so that the bottom elevation of the riverbed varies linearly with the water-surface elevation. Conductance of the riverbed material was calculated in MODFLOW by multiplying the $K_{z}$ value of the fine-grained alluvium unit, $1.15 \mathrm{~m} / \mathrm{d}$ (table 1 ), by the area of the river cell, $900 \mathrm{~m}^{2}$, and dividing that by the riverbed thickness, which was set at an estimated value of $0.47 \mathrm{~m}$. This calculation resulted in a conductance of 2,190 square meters per day $\left(\mathrm{m}^{2} / \mathrm{d}\right)$ for all river cells.
The DRN Package was assigned to upland cells in layer 1 that intersect tributaries of the Des Moines River. Drain cells were not assigned to cells in the Des Moines River valley that intersect tributaries because flow there is largely dominated by the river, and drain cells would impose too strong a boundary condition. Attributes required to define each model cell simulated by the DRN Package (drain cell) include drain elevation and conductance of the drain bed material, in square meters per day. Drain elevations for each drain cell were set at $1 \mathrm{~m}$ below the land surface (top of layer 1). Conductance of the drain bed material was calculated in MODFLOW by multiplying the $K_{z}$ value of the till unit, $0.009144 \mathrm{~m} / \mathrm{d}$ (table 1), by the area of the drain cell, $900 \mathrm{~m}^{2}$, and dividing that by the drain bed thickness in that cell, resulting in a mean conductance of about $1,790 \mathrm{~m}^{2} / \mathrm{d}$ for all drain cells over a mean riverbed thickness of about $0.007 \mathrm{~m}$. 


\section{Numerical Model Calibration}

Model calibration is the process of estimating model parameters by minimizing the differences between model simulated values and observed data. During the calibration process, model parameters are tuned to match observed data within reasonable limits and are updated to reduce the differences, or residuals, between simulated and observed data. After calibration of the numerical model is complete, the model can be used for model prediction. Observations used in model calibration also are known as calibration targets. Results of the calibration process are evaluated using the sum of squared weighted residuals between simulated and observed data.

Model calibration was completed using PEST (Doherty, 2004, 2015), which implements the Gauss-LevenbergMarquardt algorithm (Doherty and Hunt, 2010; Doherty, 2015) and the singular-value decomposition-based parameter estimation methodology (Tonkin and Doherty, 2005). The PEST calibration process includes completing a single model simulation using a user-defined set of model input parameters with a nonlinear regression method and comparing model outputs to the calibration dataset. Subsequent model runs are completed with small changes in model input parameters, and the model outputs are again compared to the calibration dataset to help generate the optimal model fits to observed data. PEST automates the calibration process to mathematically determine which input parameters to adjust for a better match between the model outputs and the calibration dataset. PEST continues the process until the optimal set of model input parameters is obtained, which provides the statistically best comparison of model outputs and the calibration dataset.

\section{Calibration Targets}

The steady-state model was calibrated using calibration targets based on inferred and observed water-table elevations representative of a winter low-flow scenario. The calibration targets were placed in the river valley to better calibrate the model in the location of the Des Moines River alluvial aquifer. The locations of the calibration targets were based on the location of the inferred or observed data point and were assigned to layer 1 (fig. 5). Daily continuous data from USGS observation well 413713093380201 (U.S. Geological Survey, 2021d) were used to calculate a mean observed water-table elevation of $240.4 \mathrm{~m}$ for December 2020 as the calibration target labeled 413713093380201 in figure 5. The water-table elevations for calibration targets labeled CT1 through CT9 in figure 5 were selected from the inferred water-table elevation map, which was based on a low downstream water-surface elevation recorded at the streamgage within the model area from January 2015 to December 2020 as described in the "Inferred Water-Table Elevation Map" section. The water-table elevation values from the contour map that were used as calibration targets were $240.1 \mathrm{~m}$ (CT1), $240.2 \mathrm{~m}$ (CT2), $240.2 \mathrm{~m}$ (CT3), $240.2 \mathrm{~m}$ (CT4), $240.1 \mathrm{~m}$ (CT5), $240.1 \mathrm{~m}$ (CT6), $240.2 \mathrm{~m}$ (CT7), $240.3 \mathrm{~m}$ (CT8), and $240.7 \mathrm{~m}$ (CT9). All calibration target values used for steady-state model calibration are available in the USGS data release associated with this report (Ha, 2022).

\section{Calibration Parameters}

Parameters adjusted during model calibration include $K_{h}$ values of the fine-grained alluvium, coarse-grained alluvium, and till units (table 1) and recharge. The $K_{h}$ value of the bedrock unit, $K_{z}$ value of all units, and ET were determined to be insensitive to calibration during the sensitivity analysis and were not adjusted during model calibration. The results of this sensitivity analysis are available in the USGS data release associated with this report (Ha, 2022). Recharge was adjusted independently during the calibration process using a recharge multiplier, which was applied uniformly to layer 1 in the $\mathrm{RCH}$ Package. Hydraulic conductivity and recharge values determined in previous studies were used to define the upper and lower allowable parameter bounds applied during model calibration (Thompson, 1984; Lucey, 1991; Gannon, 2011, 2013).

\section{Numerical Model Calibration Results}

The recharge value and $K_{h}$ values of the fine-grained alluvium, coarse-grained alluvium, and till units were adjusted during steady-state model calibration. The recharge value was adjusted from an initial value of $0.001 \mathrm{~m} / \mathrm{d}$ to an optimal value of $0.0003 \mathrm{~m} / \mathrm{d}$. The $K_{h}$ value of the fine-grained alluvium unit was adjusted from 26.28 to $13.14 \mathrm{~m} / \mathrm{d}$, the $K_{h}$ value of the coarse-grained alluvium was adjusted from 64.11 to $25.00 \mathrm{~m} / \mathrm{d}$, and the $K_{h}$ value of the till unit was adjusted from 0.09144 to $0.13716 \mathrm{~m} / \mathrm{d}$ (table 1 ).

The calibrated model was used to simulate water-table elevations in layer 1 during the steady-state period (fig. 8). These simulated water-table elevations were compared to the water level at USGS observation well 413713093380201 and elevations from the water-table elevation map, hereafter referred to as "observed water-table elevations," at the locations of the calibration targets to evaluate model performance. A plot of simulated and observed water-table elevations and a 1:1 line, where perfect model performance would be indicated by all the points falling along that line, are shown in figure 9 . The differences between simulated water-table elevations and observed water-table elevations were $-0.1 \mathrm{~m}$ for all calibration targets except CT9 and 413713093380201, which had differences of $0.2 \mathrm{~m}$, where a negative value represents an overestimation of the simulated water-table elevation value compared to the observed water-table elevation value and a positive value indicates an underestimation. Most of the simulated water-table elevation values are overestimations (fig. 9). The root mean square error of these results was $0.13 \mathrm{~m}$ and represents about 20 percent of the difference in observed water-table elevations at the calibration targets, which was $0.6 \mathrm{~m}$. A subsequent study could incorporate pump test data that would provide a greater difference in water-table elevation observations to use in model calibration and improve model performance. 


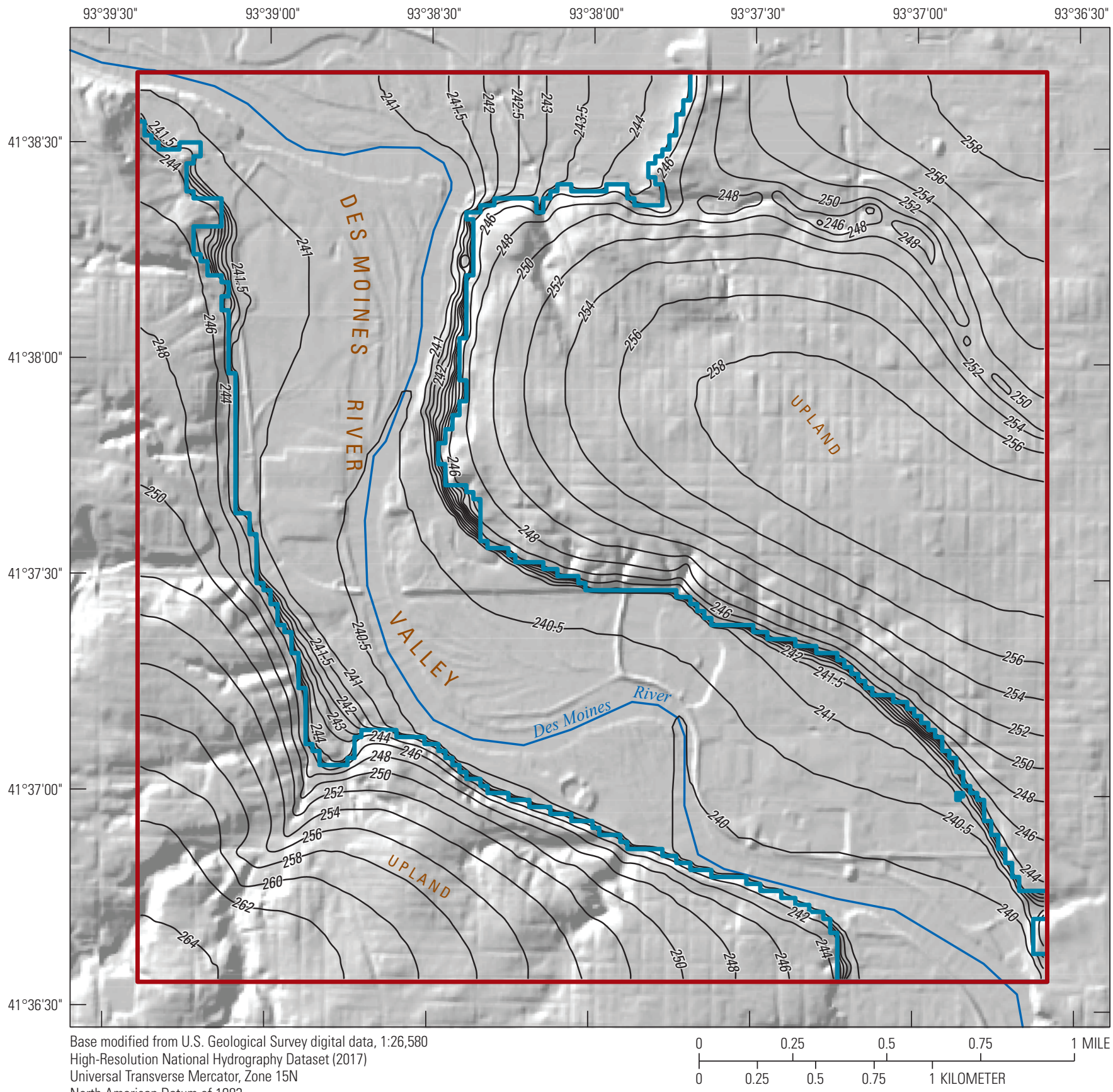

Universal Transverse Mercator, Zone 15N

North American Datum of 1983

\section{EXPLANATION}

\section{Model area boundary}

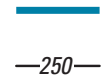

Boundary between Des Moines River valley and upland landforms

Water-level contour-Shows elevation at which water level would have stood in tightly cased wells. Contour interval 2 meters in the upland area and 0.5 meter in the Des Moines River valley. Datum is North American Vertical Datum of 1988

\section{Des Moines River centerline}

Figure 8. Simulated water-table elevations in layer 1 within the model area. 
Simulated water budget components in the model area during the stress period include inflow from the Des Moines River and its tributaries, inflow from infiltration of precipitation, outflow to ET, and outflow to the Des Moines River and its tributaries (table 2). Recharge to the groundwater system during the steady-state period is primarily from the infiltration of precipitation that is within the model area, with a smaller amount coming from seepage from the Des Moines River. Discharge from the groundwater system during the steadystate period flows primarily to the Des Moines River and its tributaries, with a smaller amount going to ET. The discrepancy between inflows to and outflows from the groundwater system was 0.01 percent, with outflows being slightly higher than inflows.

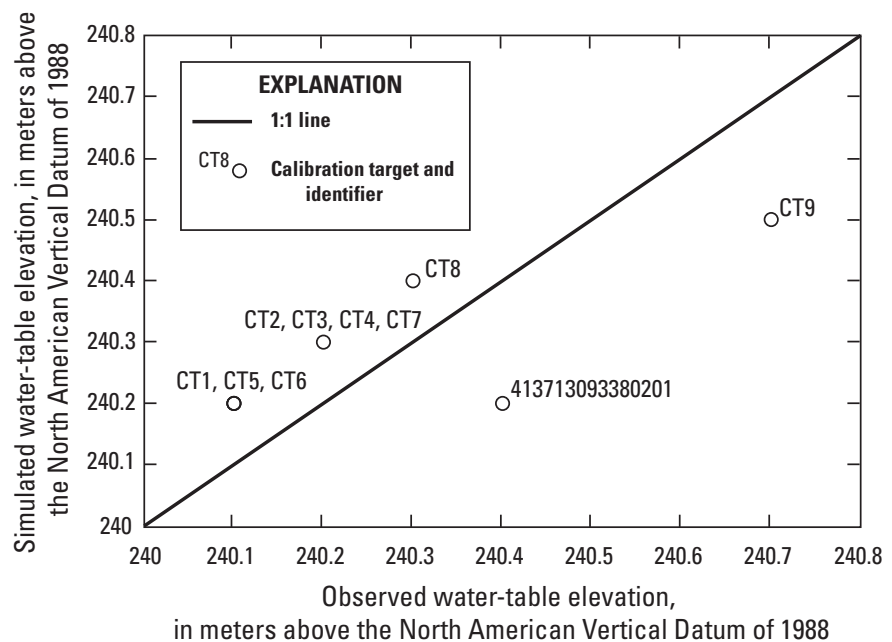

Figure 9. Simulated versus observed water-table elevations for the steady-state calibration period with a 1:1 line shown. Labels indicate the calibration target that the simulated or observed value coincides with.
Model performance was evaluated by comparing estimated and simulated contributions to streamflow within the model area. Simulated outflow from the groundwater system to river cells in the model area was $3,987 \mathrm{~m}^{3} / \mathrm{d}$ (or about $1.630 \mathrm{ft}^{3} / \mathrm{s}$; table 2). To estimate streamflow contribution in the model area, the difference was taken between simultaneous streamflow measurements recorded on December 1, 2020, at 19:15 at downstream USGS streamgage Des Moines River at 2nd Avenue at Des Moines, Iowa (05482000), and upstream USGS streamgage Des Moines River near Saylorville, Iowa (05481650; U.S. Geological Survey, 2021a), which is about $10 \mathrm{~km}$ upstream, outside of the model boundary. This date was chosen to represent winter low-flow conditions for the simultaneous streamflow measurement comparison because the monthly mean streamflow recorded at the 2nd Avenue streamgage in December 2020 was about 216 cubic feet per second $\left(\mathrm{ft}^{3} / \mathrm{s}\right)$, which is one of the lowest monthly mean values recorded at this streamgage in December since 1996. Streamflow at both streamgages at the time of this measurement had been sustained for about the previous 12 hours.

Streamflow at the 2nd Avenue streamgage at 19:15 on December 2, 2020, was about $230 \mathrm{ft}^{3} / \mathrm{s}$ (U.S. Geological Survey, 2021c), and streamflow at the Saylorville streamgage was about $219 \mathrm{ft}^{3} / \mathrm{s}$ (U.S. Geological Survey, 2021a), which is a difference of about $11 \mathrm{ft}^{3} / \mathrm{s}$. Streamflow from Beaver Creek, a tributary of the Des Moines River between these two streamgages, was estimated at $5 \mathrm{ft}^{3} / \mathrm{s}$ using USGS streamgage Beaver Creek near Grimes, Iowa (05481950; not shown; U.S. Geological Survey, 2021b). The contribution of streamflow from Beaver Creek was subtracted from the difference between simultaneous streamflow measurements made at the upstream and downstream streamgages on the Des Moines River, resulting in an estimated streamflow contribution for the model area of about $6 \mathrm{ft}^{3} / \mathrm{s}$. Simulated outflow from the groundwater system to river cells in the model area was $3,987 \mathrm{~m}^{3} / \mathrm{d}$ (or about $1.630 \mathrm{ft}^{3} / \mathrm{s}$; table 2) and was considered satisfactory based on comparison to the estimated value. The comparison validates the ability of the steady-state model to simulate groundwater conditions within the model area during winter low-flow conditions.

Table 2. Volumetric water budget for the simulated stress period.

[Values rounded to the nearest integer; $\mathrm{m}^{3}$, cubic meter; $\mathrm{m}^{3} / \mathrm{d}$, cubic meter per day; N/A, not applicable]

\begin{tabular}{|c|c|c|c|c|}
\hline \multirow[b]{2}{*}{ Water budget component } & \multicolumn{2}{|c|}{ Inflow to groundwater system } & \multicolumn{2}{|c|}{ Outflow from groundwater system } \\
\hline & $\begin{array}{c}\text { Cumulative } \\
\qquad\left(\mathrm{m}^{3}\right)\end{array}$ & $\begin{array}{l}\text { Daily } \\
\left(\mathrm{m}^{3} / \mathrm{d}\right)\end{array}$ & $\begin{array}{c}\text { Cumulative } \\
\qquad\left(\mathrm{m}^{3}\right)\end{array}$ & $\begin{array}{l}\text { Daily } \\
\left(\mathrm{m}^{3} / \mathrm{d}\right)\end{array}$ \\
\hline River & 6,226 & 201 & 123,606 & 3,987 \\
\hline Tributaries & $\mathrm{N} / \mathrm{A}$ & N/A & 23,101 & 745 \\
\hline Precipitation & 141,453 & 4,563 & $\mathrm{~N} / \mathrm{A}$ & N/A \\
\hline Evapotranspiration & N/A & N/A & 991 & 32 \\
\hline
\end{tabular}




\section{Model Limitations}

As with all numerical models of groundwater flow, the steady-state model of the Des Moines River alluvial aquifer described in this report is a simplified mathematical representation of a complex natural system. As such, there are limits to the accuracy with which it can be used to simulate the groundwater system, and it is important to acknowledge these limitations when evaluating model results. A particular limitation of this model was a lack of water-table elevation observations available for use in model calibration. Only one USGS observation well was in the model area to use for model calibration: the rest of the calibration targets were taken from the inferred water-table elevation map that was developed as part of the conceptual model. The accuracy of the model therefore depends on the accuracy of these inferred values. Although the inferred water-table elevation at the location of the USGS observation well compared favorably with the mean water level recorded there in December 2020, confidence in the accuracy of these inferred values could be improved with additional observations of water-table elevation at other locations within the model area.

During model calibration, calibration targets were clustered in the Des Moines River valley surrounding the USGS observation well. This clustering was chosen to improve the calibration of the model in this area because the purpose of the model was to simulate groundwater flow within the Des Moines River alluvial aquifer near this location. Although the steady-state model was considered to satisfactorily simulate water-table elevations in the Des Moines River alluvial aquifer based on the comparison of simulated and observed water levels at the locations of the calibration targets in the river valley, the simulated water-table elevations in the uplands cannot be considered with the same confidence. Therefore, this model is not appropriate for use to investigate groundwater flow in the uplands outside the Des Moines River alluvial aquifer.

The difference in observed water-table elevation values used in model calibration was $0.6 \mathrm{~m}$, which is not much greater than the difference between observed and simulated water-table elevations (from -0.1 to $0.2 \mathrm{~m}$ ). Pump test data for the model area could be incorporated into the calibration of a transient version of this steady-state model, which would provide a greater difference in water-table elevations and further reduce model uncertainty and error. The performance of the steady-state model in simulating groundwater flow processes in the Des Moines River alluvial aquifer was still considered satisfactory and was supported by the comparison of simulated and estimated contributions to streamflow in the model area. The steady-state model can be used to build a transient groundwater flow model for the Des Moines River alluvial aquifer.

\section{Summary}

The Des Moines River alluvial aquifer is an important source of water for Des Moines Water Works, the regional municipal water utility that provides residential and commercial water resources to the residents of Des Moines, Iowa, and surrounding municipalities. The Des Moines Water Works is cooperating with the U.S. Geological Survey (USGS) on a series of cooperative scientific investigations to evaluate the availability and resilience of groundwater resources within the Des Moines River alluvial aquifer. The USGS constructed a steady-state numerical groundwater flow model using MODFLOW-NWT to simulate water-table elevations in the Des Moines River alluvial aquifer near Prospect Park in Des Moines under winter low-flow conditions. The numerical groundwater flow model and supporting data are available in the USGS data release associated with this report, which contains the model archive.

A simple conceptual model consisting of a hydrogeologic framework, water budget, and inferred water-table elevation map was developed for the model area. Surficial sediments and bedrock were conceptualized as four hydrogeologic units: fine-grained alluvium, coarse-grained alluvium, till, and bedrock. Sources of groundwater recharge within the model area include seepage from the Des Moines River channel and infiltration from precipitation, and sources of groundwater discharge include evapotranspiration and contributions to streamflow to the Des Moines River and its tributaries. An inferred water-table elevation map was constructed based on general knowledge of hydrogeology within the model area and was used to set calibration targets for numerical model calibration. The inferred water-table elevation values were based on a low water-surface elevation value recorded at the streamgage within the model area from January 2015 to December 2020 to represent winter low-flow conditions. These values were considered to accurately represent the elevation of the water table during winter low-flow conditions because the inferred water-table elevation at the location of the observation well within the model area was similar to the monthly mean value recorded there in December 2020.

A steady-state numerical model was constructed based on the conceptual model using MODFLOW-NWT to simulate an area of about 15 square kilometers near Prospect Park in Des Moines. The numerical model framework was vertically discretized into three layers used to represent the four hydrogeologic units. The spatial extent, thickness, and hydraulic conductivities of the units assigned to model layers were determined from the conceptual model framework. Boundary conditions were simulated using the River, Drain, Recharge, and Evapotranspiration Packages, the values for which also were determined using the conceptual model framework. 
The steady-state model was calibrated with Parameter ESTimation software using elevation values from the inferred water-table map. Parameters adjusted during model calibration include recharge and the horizontal hydraulic conductivity of the coarse-grained alluvium, fine-grained alluvium, and till units. The calibrated model was then used to simulate watertable elevations in the model area. The difference between observed water-table elevations and simulated water-table elevations was -0.1 meter at the majority of calibration targets, with the negative value indicating an overestimation of the simulated water-table elevation value compared to the observed water-table elevation value, and the root mean square error was 0.13 meter, which represents about 20 percent of the difference in observed water-table elevations. The simulated value of contributions to streamflow within the model area was considered similar to the estimated value, increasing confidence in the ability of the model to accurately represent the groundwater flow system in the Des Moines River alluvial aquifer in the model area during winter low-flow conditions. A future study could incorporate pump test data to provide a greater difference in water-table elevation observations for use in model calibration.

\section{References Cited}

Bettis, E.A., III, and Hoyer, B.E., 1986, Late Wisconsinan and Holocene landscape evolution and alluvial stratigraphy in the Saylorville Lake area, central Des Moines River Valley, Iowa: Iowa City, Iowa, Iowa Geological Survey Open File Report 86-1, 82 p. plus appendixes.

Bettis, E.A., III, Pearson, J., Edwards, M., Gradwohl, D., Osborn, N., Kemmis, T., and Quade, D., 1988, Natural history of Ledges State Park and the Des Moines Valley in Boone County: Geological Society of Iowa Guidebook 48, 71 p.

Clark, P.U., Clague, J.J., Curry, B.B., Dreimanis, A., Hicock, S.R., Miller, G.H., Berger, G.W., Eyles, N., Lamothe, M., Miller, B.B., Mott, R.J., Oldale, R.N., Stea, R.R., Szabo, J.P., Thorleifson, L.H., and Vincent, J.S., 1993, Initiation and development of the Laurentide and Cordilleran Ice Sheets following the last interglaciation: Quaternary Science Reviews, v. 12, no. 2, p. 79-114, accessed October 2021 at https://doi.org/10.1016/0277-3791(93)90011-A.

Devlin, J.F., 2015, HydrogeoSieveXL-An Excel-based tool to estimate hydraulic conductivity from grain-size analysis: Hydrogeology Journal, v. 23, no. 4, p. 837-844. [Also available at https://doi.org/10.1007/s10040-015-1255-0.] [Erratum published December 14, 2016, and available at https://doi.org/10.1007/s10040-016-1512-x.]
Doherty, J., 2004, PEST-Model-independent parameter estimation-User manual (5th ed.): Watermark Numerical Computing, [variously paged], accessed March 30, 2018, at https://www.pesthomepage.org/.

Doherty, J., 2015, Calibration and uncertainty analysis for complex environmental models: Brisbane, Australia, Watermark Numerical Computing, 226 p.

Doherty, J.E., and Hunt, R.J., 2010, Approaches to highly parameterized inversion-A guide to using PEST for groundwater-model calibration: U.S. Geological Survey Scientific Investigations Report 2010-5169, 59 p., accessed June 28, 2020, at https://doi.org/10.3133/sir20105169.

Gannon, J.M., 2011, Groundwater availability modeling, Des Moines River aquifer, Palo Alto and Emmet Counties, Iowa: Iowa Department of Natural Resources, Iowa Geological and Water Survey Water Resources Investigation Report no. 4, 41 p., accessed May 2020 at http://publications.iowa. gov $/ 26587 /$.

Gannon, J.M., 2013, Groundwater availability modeling under drought conditions, Lower Raccoon River aquifer, Dallas and Polk Counties, Iowa-Drought assessment: Iowa Department of Natural Resources, Iowa Geological and Water Survey Water Resources Investigation Report 7, 53 p., accessed May 2020 at http://publications.iowa.gov/id/ eprint/26590.

Gruhn, L.R., Bristow, E.L., and White, E.A., 2021, Geophysical data collected in the Des Moines River, Beaver Creek, and the Des Moines River floodplain, Des Moines, Iowa, 2018: U.S. Geological Survey data release, https://doi.org/10.5066/P9B9AVKJ.

Ha, W.S., 2022, MODFLOW-NWT model used to simulate groundwater levels in the Des Moines River alluvial aquifer near Des Moines, Iowa: U.S. Geological Survey data release, https://doi.org/10.5066/P9F3CKLC.

Harbaugh, A.W., 2005, MODFLOW-2005-The U.S. Geological Survey modular ground-water model-The ground-water flow process: U.S. Geological Survey Techniques and Methods, book 6, chap. A16, [variously paged]. [Also available at https://doi.org/10.3133/tm6A16.]

Harbaugh, A.W., Banta, E.R., Hill, M.C., and McDonald, M.G., 2000, MODFLOW-2000, the U.S. Geological Survey modular ground-water model-User guide to modularization concepts and the ground-water flow process: U.S. Geological Survey Open-File Report 2000-92, 121 p. [Also available at https://doi.org/10.3133/ofr200092.]

Iowa Geological Survey, 2018, GeoSam-Iowa Geological Survey: Iowa Geological Survey digital data, accessed May 6, 2020, at https://www.iihr.uiowa.edu/igs/ geosam/home. 
Iowa State University, 2020, Iowa Environment Mesonet: Iowa State University database, accessed May 2020 at https://mesonet.agron.iastate.edu/sites/site.php?station= AMFI4\&network=ISUSM.

Langevin, C.D., Hughes, J.D., Banta, E.R., Niswonger, R.G., Panday, S., and Provost, A.M., 2017, Documentation for the MODFLOW 6 Groundwater Flow Model: U.S. Geological Survey Techniques and Methods, book 6, chap. A55, 197 p., accessed May 2020 at https://doi.org/10.3133/tm6A55.

Lucey, K.J., 1991, Analysis of the ground-water flow system, geochemistry, and underseepage in the vicinity of the Red Rock Dam near Pella, Iowa: U.S. Geological Survey WaterResources Investigations Report 91-4092, 68 p., 1 pl. [Also available at https://doi.org/10.3133/wri914092.]

McDonald, M.G., and Harbaugh, A.W., 1988, A modular three-dimensional finite-difference ground-water flow model: U.S. Geological Survey Techniques of WaterResources Investigations, book 6, chap. A1, 586 p. [Also available at https://doi.org/10.3133/twri06A1.]

National Oceanic and Atmospheric Administration, 2021a, Data tools - 1981-2010 normals: National Centers for Environmental Information digital data, accessed May 11, 2020, at https://www.ncdc.noaa.gov/cdo-web/ datatools/normals.

National Oceanic and Atmospheric Administration, 2021b, NOWData-NOAA online weather data: National Weather Service digital data, accessed June 1, 2021, at https:/www.weather.gov/wrh/climate?wfo=dmx.

Niswonger, R.G., Panday, S., and Ibaraki, M., 2011, MODFLOW-NWT, a Newton formulation for MODFLOW-2005: U.S. Geological Survey Techniques and Methods, book 6, chap. A37, 44 p. [Also available at https://doi.org/10.3133/tm6A37.]

Pope, J.P., Witzke, B.J., Anderson, R.R., Ludvigson, G.A., Bunker, B.J., and Greeney, S., 2002, Bedrock geology of south-central Iowa: Iowa Geological Survey Open File Map 02-1, prepared by Iowa Department of Natural Resources, scale 1:250,000. [Also available at https://www.iihr. uiowa.edu/igs/publications/uploads/ofm-2002-1.pdf.]

Quade, D.J., Giglierano, J.P., Bettis, E.A., III, and Artz, J.A., 2003, Surficial geologic materials of Polk County, Iowa: Iowa Geological Survey Open File Map 2003-3, scale 1:100,000, accessed May 28, 2020, at http://publications .iowa.gov/26206/1/ofm-2003-3.pdf.

State of Iowa, 2010, Three meter digital elevation model of Polk County, Iowa, derived from LiDAR: State of Iowa digital data, accessed May 2020 at https:/geodata.iowa.gov/ pages/three-meter-digital-elevation-model-countydownloads.
Thompson, C.A., 1984, Hydrogeology and water quality of the Upper Des Moines River alluvial aquifer: Iowa Geological Survey Open File Report 84-5, 170 p., 2 pls.

Todd, D.K., 1980, Groundwater hydrology (2d ed.): New York, John Wiley \& Sons, 535 p.

Tonkin, M.J., and Doherty, J., 2005, A hybrid regularized inversion methodology for highly parameterized environmental models: Water Resources Research, v. 41, no. 10, accessed May 2020 at https://doi.org/10.1029/ 2005 WR003995.

U.S. Census Bureau, 2019, QuickFacts_-Des Moines city, Iowa: U.S. Census Bureau web page, accessed May 27, 2021, at https://www.census.gov/quickfacts/ desmoinescityiowa.

U.S. Geological Survey, 2021a, USGS 05481650 Des Moines River near Saylorville, IA, in USGS water data for the Nation: U.S. Geological Survey National Water Information System database, accessed December 2, 2021, at https://doi.org/10.5066/F7P55KJN. [Site information directly accessible at https://waterdata.usgs.gov/nwis/uv? site_no $=05481650$.]

U.S. Geological Survey, 2021b, USGS 05481950 Beaver Creek near Grimes, IA, in USGS water data for the Nation: U.S. Geological Survey National Water Information System database, accessed December 2, 2021, at https://doi.org/ 10.5066/F7P55KJN. [Site information directly accessible at https://waterdata.usgs.gov/ia/nwis/uv?site_no=05481950.]

U.S. Geological Survey, 2021c, USGS 05482000 Des Moines River at 2nd Avenue at Des Moines, IA, in USGS water data for the Nation: U.S. Geological Survey National Water Information System database, accessed June 7, 2021, at https://doi.org/10.5066/F7P55KJN. [Site information directly accessible at https://waterdata.usgs.gov/nwis/uv? site_no $=05482000$.]

U.S. Geological Survey, 2021d, USGS 413713093380201 079N24W27DAC 2020RDP, in USGS water data for the Nation: U.S. Geological Survey National Water Information System database, accessed April 15, 2021, at https://doi.org/ 10.5066/F7P55KJN. [Site information directly accessible at https://waterdata.usgs.gov/nwis/inventory/?site_no= 413713093380201.]

Winston, R.B., 2018, Online guide to MODFLOW-2005: U.S. Geological Survey web page, accessed March 6, 2020, at https://water.usgs.gov/ogw/modflow/MODFLOW2005-Guide/. 
Witt, A., 2017, Hydrogeological and geochemical investigation of recharge (leakage) through till aquitards to buriedvalley aquifers in central and northeastern Minnesota: Iowa City, Iowa, Iowa State University, master's thesis, $168 \mathrm{p}$. [Also available at https://lib.dr.iastate.edu/etd/15462.]
Witzke, B.J., Anderson, R.R., and Pope, J.P., 2010, Iowa bedrock geologic map: Iowa Geological and Water Survey Open File Map 2010-1, prepared by Iowa Department of Natural Resources, accessed May 28, 2020, at https://iowageodata2.s3.us-east-2.amazonaws.com/ geoscientificInformation/bedrock/Bedrock_Geologic_ Map.zip. 
For more information about this publication, contact: Director, USGS Central Midwest Water Science Center 400 South Clinton Street, Suite 269

lowa City, IA 52240

319-337-4191

For additional information, visit: https://www.usgs.gov/ centers/cm-water

Publishing support provided by the

Lafayette and Rolla Publishing Service Centers 
